\title{
A Multi-Level World Comprehensive Neural Network Model for Maximum Annual Solar Irradiation on a Flat Surface
}

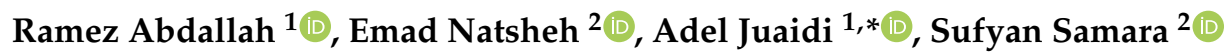 \\ and Francisco Manzano-Agugliaro ${ }^{3, * \mathbb{D}}$ \\ 1 Department of Mechanical Engineering, Faculty of Engineering \& Information Technology, \\ An-Najah National University, P.O. Box 7 Nablus, Palestine; ramezkhaldi@najah.edu \\ 2 Department of Computer Engineering, Faculty of Engineering \& Information Technology, \\ An-Najah National University, P.O. Box 7 Nablus, Palestine; e.natsheh@najah.edu (E.N.); \\ sufyan_sa@najah.edu (S.S.) \\ 3 Department of Engineering, University of Almeria, ceiA3, 04120 Almeria, Spain \\ * Correspondence: adel@najah.edu (A.J.); fmanzano@ual.es (F.M.-A.)
}

Received: 31 October 2020; Accepted: 2 December 2020; Published: 4 December 2020

\begin{abstract}
With the growing demand for clean and economically feasible renewable energy, solar photovoltaic (PV) system usage has increased. Among many factors, the tilt and azimuth angles are of great importance and influence in determining the photovoltaic panel's efficiency to generate electricity. Although much research was conducted related to solar PV panels' performance, this work critically determined the tilt and azimuth angles for PV panels in all countries worldwide. The optimum tilt and azimuth angles are estimated worldwide by the photovoltaic geographic information system (PVGIS). Also, annual and average daily solar irradiation incident on the tilted and oriented plate optimally (AR1 and DR1) are calculated. Besides, annual and average daily solar irradiation incident on plate tilt optimally and oriented because of the south in the northern hemisphere and because of the north in the southern hemisphere (AR2 and DR2) are estimated. PVGIS is also used to calculate the annual and average daily solar irradiation incident on the horizontal plate (AR3 and DR3). The data collected from PVGIS are used to develop an efficient and accurate artificial neural network model based on feed-forward neural network approach. This model is an essential subpart that can be used in an embedded system or an online system for further PV system analysis and optimization. The developed neural model reflected very high accuracy in predicting the PV panels' optimal tilt and azimuth angles worldwide. The benefit of tilting is generally increased by increasing the latitude. As the latitude increases, the tilt factor $(F)$ increases because of the increase in the optimum tilt angle by increasing the latitude. The optimal orientation is due to the north in the southern hemisphere and due to the south in the northern hemisphere for most cities worldwide. In sum, it can be concluded that the optimum tilt angle is equal to or greater than the latitude until the latitude $30^{\circ}$. The optimum tilt angle becomes less than the latitude, and the difference is increased until it reaches more than $20^{\circ}$. Hence in this study the aim is to develop a simple neural network model which can accurately predict the annual radiation and optimum tilt and azimuth angle in any region of the world and can be easily implemented in a low-cost microcontroller.
\end{abstract}

Keywords: optimal tilt angle; PV system; solar photovoltaic; solar irradiation; Levenberg Marquardt algorithm; feed-forward neural network 


\section{Introduction}

Solar energy is considered as an original and unlimited source of energy and it also works to enhance energy security and sustainability, and this in turn leads to reducing pollution; also, to keep the prices of fossil fuels lower than others. It also reduces the cost of mitigating climate change $[1,2]$. Thus, according to IRENE [3], the production of solar photovoltaic (PV) energy is increasing annually. For example, the existing solar PV energy production increased more than 27 times from the production ten years ago; in 2009, it was less than 23 gigawatts. The solar PV installation capacity reached 627 gigawatts in 2019 compared to 512 in 2018 [3].

Because of rapid technological progress and reduce costs, solar PV will have an essential role in reaching the sustainable development goals (SDGs) by 2030 [4], increase the share of renewable energy in the universal electricity sector, in addition to the provision of electricity for remote areas [5-9].

The amount of solar energy produced by a solar PV panel can be determined based on the local insolation. However, it is affected by the solar PV panels' tilt and orientation angles [10-13]. Thus, an appropriate tilt and orientation angle must be applied to achieve the maximum produced energy for a specific location [14-17]. Although one can use a solar tracking system that follows the sun to receive the maximum amount of daily energy, on the other hand, solar tracking systems are expensive and additional energy is needed for its operation [2].

Thus, it is commonly convenient to fix the solar PV on an optimum orientation and tilt angle [18-20]. Therefore, solar PV panels are recommended to be placed at the optimum tilt and orientation angle to obtain the yearly maximum energy production $[10,11]$.

Many authors have attempted various analytical, simulations, and experimental work to obtain the optimum angles [21,22]. A general approximate rule for optimizing angles is that a given location's tilt angle is approximately equal to its latitude. The orientation angle should be south for Northern Hemisphere and north for Southern Hemisphere [23].

The present study used data from the Photovoltaic Geographical Information System (PVGIS), 2019 [24] for estimating optimum angles. The PVGIS gives solar irradiation on a horizontal surface and a surface tilted from horizontal or oriented because of the south. Moreover, the PVGIS provides an optimum tilt and azimuth angle that give the maximum yearly solar irradiation. The PVGIS is employing irradiation data based on satellite images. Based on satellite images, all databases provide hourly solar irradiation estimates. This means that PVGIS can be employed for any place, no matter how far from particular meteorological stations.

This study aims to find an artificial neural network model that can calculate an optimum tilt and azimuth angle in any world region. This model can be used inside an embedded system or as an online service. For an artificial neural network to be constructed and trained, it is required to obtain data from many locations worldwide.

The used data are obtained by PVGIS. First, the optimum tilt angles that give the maximum yearly solar irradiation for surfaces directed because of the south in the northern hemisphere and north in the southern hemisphere are calculated. Second, the optimum azimuth angles accompanying the optimum tilt angle are also calculated. Third, the annual and average daily irradiation in different regions all over the world is calculated for surfaces tilted with optimum tilt angles and directed because of the south in the northern hemisphere and because of north in the southern hemisphere (AR2 and DR2) and surfaces tilted with optimum tilt angle and oriented with optimum azimuth angles (AR1 and DR1). Fourth, the annual and average daily irradiations for horizontal surfaces are calculated (AR3 and DR3). Lastly, the tilt fact $(\mathrm{F})$, which can be defined as the ratio of the irradiation collected by a tilted surface to the irradiation collected by a horizontal surface, is calculated.

Although one can use mathematical or statistical modules to calculate that based on some rules or conditions, these approaches tend to be very difficult and inaccurate when such conditions are hard to predict, has a non-linear form, or with a pattern that is hard to find [25]. Adding to that, for their hardware implementation they require expensive microcontrollers. 
The best output energy of a PV panel depends mainly on the maximum vertical amount of solar radiation that hits the PV panel surface. This maximum vertical solar irradiation changes according to the tilt and azimuth angles. Artificial intelligence can help increase this amount of solar irradiation by finding optimum tilt and azimuth angles, which is challenging to model accurately using mathematical or statistical modules, even for a single location [26].

Neural networks are characterized by being capable to learn by themselves and produce an output that is not limited to the input provided to them. Moreover, even if a neuron is not responding or a piece of information is missing, the network can detect the fault and still produce the output. Hence in this study, the aim is to develop a simple neural network model that can accurately predict the annual irradiation and optimum tilt and azimuth angle in any region of the world and can be easily implemented in a low-cost microcontroller.

\section{Literature Review}

Obtaining the photovoltaic system's optimum tilt angle is a significant issue because it helps to effectively transform the amount of sunlight received into energy [27]. Numerous studies have used various research approaches to find a tilt angle that maximizes the amount of irradiation received by the solar panel [27]. Such models include Hay's model, PVsyst simulation, PV-Simulation model, Nijegorodov equations, Harmony search meta-heuristic algorithm, PVWatts program, PVGIS program, particle swarm optimization (PSO) estimator, analytical method, MATLAB software, Oracle Crystal Ball software, and Gradient Boosting Algorithm. Table 1 summarizes these methods.

Kim Gi et al. [11] used a machine learning approach to find the optimum tilt angle of a PV panel to maximize the energy obtained from the PV panel. Although the analysis was conducted in a single area, and all PV panels shared similar geometric attributes, the optimal angles varied to certain degrees.

Artificial intelligence techniques can be employed in many problems. Their importance is realized in the ability to learning and adapt to new variations efficiently. This ability makes these techniques a promising solution in finding optimum tilt and azimuth angles for PV panels worldwide with high accuracy. While some attempts to explore the benefits these techniques offer [26,27], there is insufficient research in this field for such techniques.

This research provides an estimate of optimum tilt angles for (PV) panels for all countries worldwide. 
Table 1. Shows the optimum tilt angles using different methods for several countries worldwide from 1988 to 2020.

\begin{tabular}{|c|c|c|c|c|}
\hline Country or Region & City & $\begin{array}{l}\text { Latitude }(\varphi) \\
\left({ }^{\circ}\right)\end{array}$ & Optimum Tilt Angle $(\beta)\left(^{\circ}\right)$ Annually & Reference \\
\hline Jordan & Mu'tah & 31.7 & 28.5 & A mathematical model is developed [28]. \\
\hline Egypt & Assiut & 27.2 & 27 & Moncos (1994) developed a mathematical model [29]. \\
\hline Spain & Valencia & 28.5 & 31 & $\begin{array}{l}\text { The Hay model was used to assess the hourly variance of the } \\
\text { optimal tilt angle for a solar collector facing south and to } \\
\text { measure the annual average of this angle [30]. }\end{array}$ \\
\hline Darussalam & Brunei & 4.5 & 3.3 & A mathematical model was used [31]. \\
\hline \multirow{8}{*}{ China } & Beijing & 39.9 & 39.2 & \multirow{8}{*}{ A mathematical model is developed [32]. } \\
\hline & Kunming & 24.9 & 27.9 & \\
\hline & Shanghai & 31.2 & 28 & \\
\hline & Guangzhou & 23.1 & 22 & \\
\hline & Chengdu & 30.6 & 23 & \\
\hline & Xi'an & 34.3 & 30.1 & \\
\hline & Yinchuang & 38.5 & 38.3 & \\
\hline & Shenyang & 41.8 & 40.3 & \\
\hline Turkey & Izmir & 38.4 & $\begin{array}{c}\text { June: } 0 \\
\text { December: } 61\end{array}$ & A mathematical model is developed [33]. \\
\hline Syria & Damascus & 33.5 & 30.56 & A mathematical model is used [34]. \\
\hline \multirow{6}{*}{ Iran } & Zahedan & 29.5 & 26.70 & \multirow{6}{*}{$\begin{array}{l}\text { A more precise equation than the Nijegorodov one is formed } \\
\text { to measure the monthly optimum tilt angle using a new } \\
\text { correlation for each month [35]. }\end{array}$} \\
\hline & Birjand & 32.9 & 29.93 & \\
\hline & Shraz & 52.9 & 25.88 & \\
\hline & Tabas & 33.6 & 30.16 & \\
\hline & Yazd & 31.9 & 29.05 & \\
\hline & Kerman & 36.7 & 23.95 & \\
\hline \multirow{7}{*}{ Mediterranean Region } & Gaza Strip (Palestine) & 31.5 & 32.1 & \multirow{7}{*}{$\begin{array}{l}\text { As a function of the tilt angle, a mathematical model is used to } \\
\text { measure the solar radiation on a tilted surface [36]. }\end{array}$} \\
\hline & Damascus (Syria) & 33.5 & 33.7 & \\
\hline & Beirut (Lebanon) & 33.9 & 33.8 & \\
\hline & Tunis (Tunisia) & 33.9 & 35.2 & \\
\hline & Seville (Spain) & 37.4 & 36.6 & \\
\hline & & & 41.8 & \\
\hline & Milan (Italy) & 45.5 & $\begin{array}{l}\text { Summer: } \beta=\varphi-15^{\circ} \\
\text { Winter: } \beta=\varphi+15^{\circ}\end{array}$ & \\
\hline Jordan & Northern Jordan & $32.5^{\circ}$ & $\begin{array}{l}30 \\
\text { Summer: } 10 \\
\text { Winter: } 50\end{array}$ & $\begin{array}{l}\text { Based on the results of the PVsyst simulation for Northern } \\
\text { Jordan [37]. }\end{array}$ \\
\hline
\end{tabular}


Table 1. Cont.

\begin{tabular}{|c|c|c|c|c|}
\hline Austria and Germany & Germany & 47.5 & $30-45$ & $\begin{array}{l}\text { A PV-simulation model is provided for the measurement of } \\
\text { angle-dependent PV performance. } \\
\text { For Germany and Austria, a linear power and simplified } \\
\text { dispatch model was calibrated and used [38]. } \\
\text { A PV-simulation model is provided for the measurement of } \\
\text { angle-dependent PV performance. } \\
\text { For Germany and Austria, a linear power and simplified } \\
\text { dispatch model was calibrated and used [38]. }\end{array}$ \\
\hline \multirow{5}{*}{ Iran } & Tehran & 35.7 & 35.7 & \multirow{5}{*}{$\begin{array}{l}\text { For measuring solar radiation on a tilted surface, a } \\
\text { mathematical model is suggested. } \\
\text { The maximum angle of incidence is detected using the } \\
\text { Gravitational Search Algorithm (GSA) [39]. }\end{array}$} \\
\hline & Isfahan & 36.5 & 32 & \\
\hline & Shiraz & 29.6 & 29.4 & \\
\hline & Mashhad & 36.3 & 36.2 & \\
\hline & Tabriz & 38.1 & 38 & \\
\hline Kosovo & Pristina & 42.7 & $\begin{array}{c}34.7 \\
\text { Summer: } 8.9 \\
\text { Spring: } 25.7 \\
\text { Autumn: } 50.9 \\
\text { Winter: } 62.1\end{array}$ & $\begin{array}{l}\text { Based on isotropic sky analysis models, namely Liu and } \\
\text { Jordan models, the incident plane's solar radiation is } \\
\text { calculated [40]. }\end{array}$ \\
\hline \multirow[b]{2}{*}{ China } & Sanya & 11.5 & -18 (June) to 49.9 (Dec.) & \multirow[b]{2}{*}{$\begin{array}{l}\text { The algorithm Harmony (meta-heuristic) determines the } \\
\text { azimuth angle and optimum tilt [41]. The findings are built on } \\
\text { the ergodic mechanism [41]. }\end{array}$} \\
\hline & $\begin{array}{l}\text { Shanghai } \\
\text { Zhengzhou } \\
\text { Harbin } \\
\text { Mohe } \\
\text { Lhasa }\end{array}$ & $\begin{array}{l}31.2 \\
34.7 \\
45.8 \\
52.9 \\
29.7\end{array}$ & $\begin{array}{l}-7.6 \text { (June) to } 61.4 \text { (Dec.) } \\
5.5 \text { (June) to } 64.3 \text { (Dec.) } \\
12.6 \text { (June) to } 73.7 \text { (Dec.) } \\
16.6 \text { (June) to } 80.0 \text { (Dec.) } \\
-8.9 \text { (June) to } 59.9 \text { (Dec.) }\end{array}$ & \\
\hline \multirow{16}{*}{$\begin{array}{c}\text { All } \\
\text { Countries Worldwide }\end{array}$} & Canada (Montreal) & 45.5 & 37 & \multirow{16}{*}{$\begin{array}{l}\text { This study uses the PVWatts program to calculate the optimal } \\
\text { tilt angles for all countries worldwide [42]. }\end{array}$} \\
\hline & Bordeaux (France) & 44.8 & 33 & \\
\hline & Cologne (Germany) & 50.9 & 32 & \\
\hline & Hong Kong & 22.4 & 20 & \\
\hline & Rajko (India) & 42.1 & 24 & \\
\hline & Beek (Netherlands) & 50.9 & 34 & \\
\hline & Castellón (Spain)ón & 39.1 & 36 & \\
\hline & Austin, TX (United States) & 30.3 & 28 & \\
\hline & London (United Kingdom) & 51.5 & 34 & \\
\hline & Jerusalem (Palestine) & 31.8 & 28 & \\
\hline & Casablanca (Morocco) & 33.6 & 28 & \\
\hline & Beirut (Lebanon) & 33.9 & 28 & \\
\hline & Amman (Jordan) & 31.9 & 28 & \\
\hline & Tehran (Iran) & 35.68 & 31 & \\
\hline & Aswan (Egypt) & 24.1 & 24 & \\
\hline & $\begin{array}{c}\text { Abu Dhabi (United Arab } \\
\text { Emirates) }\end{array}$ & 24.5 & 25 & \\
\hline
\end{tabular}


Table 1. Cont.

\begin{tabular}{|c|c|c|c|c|}
\hline Cyprus & Famagusta & 35.1 & $\begin{array}{l}28 \text { to } 30 \\
\text { Summer: } 20 \\
\text { Winter: } 50\end{array}$ & $\begin{array}{c}\text { PV simulation software will be used to determine the average } \\
\text { solar radiation on different tilt. From this, to assess an optimal } \\
\text { tilt angle, the peak annual average solar radiation shall be } \\
\text { obtained on various tilted surfaces [43]. }\end{array}$ \\
\hline \multirow[t]{2}{*}{ Palestine } & \multirow{2}{*}{$\begin{array}{l}\text { West Bank } \\
\text { Gaza Strip }\end{array}$} & \multirow[t]{2}{*}{31.9} & \multirow[t]{2}{*}{29} & $\begin{array}{l}\text { 1. For determining the optimum tilt angle, a mathematical } \\
\text { model is used [20]. }\end{array}$ \\
\hline & & & & 2. PVWatts \\
\hline India & $\begin{array}{l}\text { Minicoy } \\
\text { Ahmadabad } \\
\text { New Delhi }\end{array}$ & $\begin{array}{c}8.3 \\
23.0 \\
28.6\end{array}$ & $\begin{array}{l}\text { PSO Estimator } \\
10.51 \\
25.83 \\
26.92\end{array}$ & $\begin{array}{l}\text { 1. To find an optimal tilt angle, a model-driven optimization } \\
\text { focus has been proposed, such as a particle swarm } \\
\text { optimization (PSO) estimator [44] } \\
\text { 2. Analytical method }\end{array}$ \\
\hline Ghana & Kumasi & 6.7 & 10 & $\begin{array}{l}\text { System simulation RETScreen } 4 \text {. } \\
\text { For all the three systems' orientation, the electrical energy } \\
\text { output produced by the solar module was calculated [45]. }\end{array}$ \\
\hline Turkey & $\begin{array}{l}\text { Antalya } \\
\text { Kayseri } \\
\text { Trabzon }\end{array}$ & $\begin{array}{l}36.9 \\
38.7 \\
41.0\end{array}$ & $\begin{array}{l}\text { Winter: } \beta=\varphi+17^{\circ} \\
\text { Spring: } \beta=\varphi-18^{\circ} \\
\text { Summer: } \beta=\varphi-34^{\circ} \\
\text { Autumn: } \beta=\varphi+7^{\circ} \\
\text { Annual: } \beta=\varphi-7^{\circ}\end{array}$ & $\begin{array}{l}\text { For the Northern Hemisphere and sample provinces, various } \\
\text { mathematical models have been developed. PVGIS, NASA, } \\
\text { and other approaches [46]. }\end{array}$ \\
\hline Iran & $\begin{array}{l}\text { Bandar Abbas } \\
\text { Yazd } \\
\text { Isfahan } \\
\text { Tehran } \\
\text { Urmia }\end{array}$ & $\begin{array}{l}27.13 \\
31.54 \\
32.57 \\
35.41 \\
37.32\end{array}$ & $\begin{array}{c}18.84 \\
21.47 \\
22.04 \\
23.59 \\
23.27 \\
\beta=0.4663 \varphi+6.5489^{\circ} \\
\end{array}$ & $\begin{array}{c}\text { The optimal tilt angle is calculated using a distributed } \\
\text { software developed on MATLAB. Based on particle swarm } \\
\text { optimization (PSO) approach [47]. }\end{array}$ \\
\hline Indonesia & Bukit Jimbaran Bali & 5.4 & $\begin{array}{l}\varphi \text { from } 12-18 \text { in the azimuth of } 0 . \\
\text { (Apr. to Sep.): } 32 \\
\text { (Oct. to Mar.): } 24\end{array}$ & $\begin{array}{c}\text { Simulations found that for fixed solar panels in a year. Data of } \\
\text { solar radiation and the simulation of PV system are from } \\
\text { Metronome } 7.2[48] .\end{array}$ \\
\hline USA & Eaton County, Michigan & 39.7 & 42.7 & $\begin{array}{l}\text { Oracle Crystal Ball program using Microsoft Excel (OptQuest } \\
\text { Solver Engine) was used to calculate optimal tilt angles [49]. }\end{array}$ \\
\hline South Korea & Daegu City & 35.9 & 1 to 29 & $\begin{array}{l}\text { Optimization model using machine learning algorithms: } \\
\text { Gradient Boosting Algorithm [27]. }\end{array}$ \\
\hline Norway & Trondheim & 63.4 & 52 & \\
\hline France & Paris & 48.9 & 43 & A proposed approach to use real historical solar spectra to test \\
\hline Egypt & Cairo & 30.0 & 29 & a panel's tilt at a given location rigorously [50]. \\
\hline Kenya & Nairobi & -1.3 & 3 & \\
\hline
\end{tabular}




\section{Methodology}

In this work, an artificial neural network is used to find the optimum tilt and azimuth angles that yield maximum energy from PV panels in any worldwide location. To effectively build such neural networks, training data is sampled from many locations worldwide using PVGIS (Photovoltaic Geographical Information System, 2019) [24]. PVGIS provides solar irradiation on a horizontal surface and a surface tilted from horizontal or oriented because of the south. Moreover, the PVGIS provides an optimum tilt and azimuth angle that gives the maximum yearly solar irradiation. The PVGIS employs irradiation data based on satellite images. Satellite images are used to collect solar irradiation data. The different satellites available in PVGIS are:

- PVGIS-SARAH: CM SAF [51] and the PVGIS [24] team have calculated these data covering Europe, Africa, most of Asia, and parts of South America.

- $\quad$ PVGIS-NSRDB: These data have been supplied by the National Renewable Energy Laboratory (NREL) [52] and is part of the National Solar Irradiation Database.

- PVGIS-CMSAF: CM SAF collaboration [51] have calculated these data covering Europe, Africa, and parts of South America.

- $\quad$ PVGIS uses two more satellites to cover high-latitude areas not covered by previous satellites.

- PVGIS-ERA5: This new re-analysis product is obtained from ECMWF [53]. It covers all over the world on an hourly basis and is used by PVGIS for Europe.

- PVGIS-COSMO: COSMO-REA6 is a regional re-analysis product, covering Europe at hourly time resolution.

Based on the satellite images, all databases provide hourly solar irradiation estimates. This means that PVGIS can be employed for any place, no matter how far from particular meteorological stations.

The PVGIS is used to obtain data for training and validating the developed artificial neural network model. Figure 1 shows the locations around the world used to gather training data.

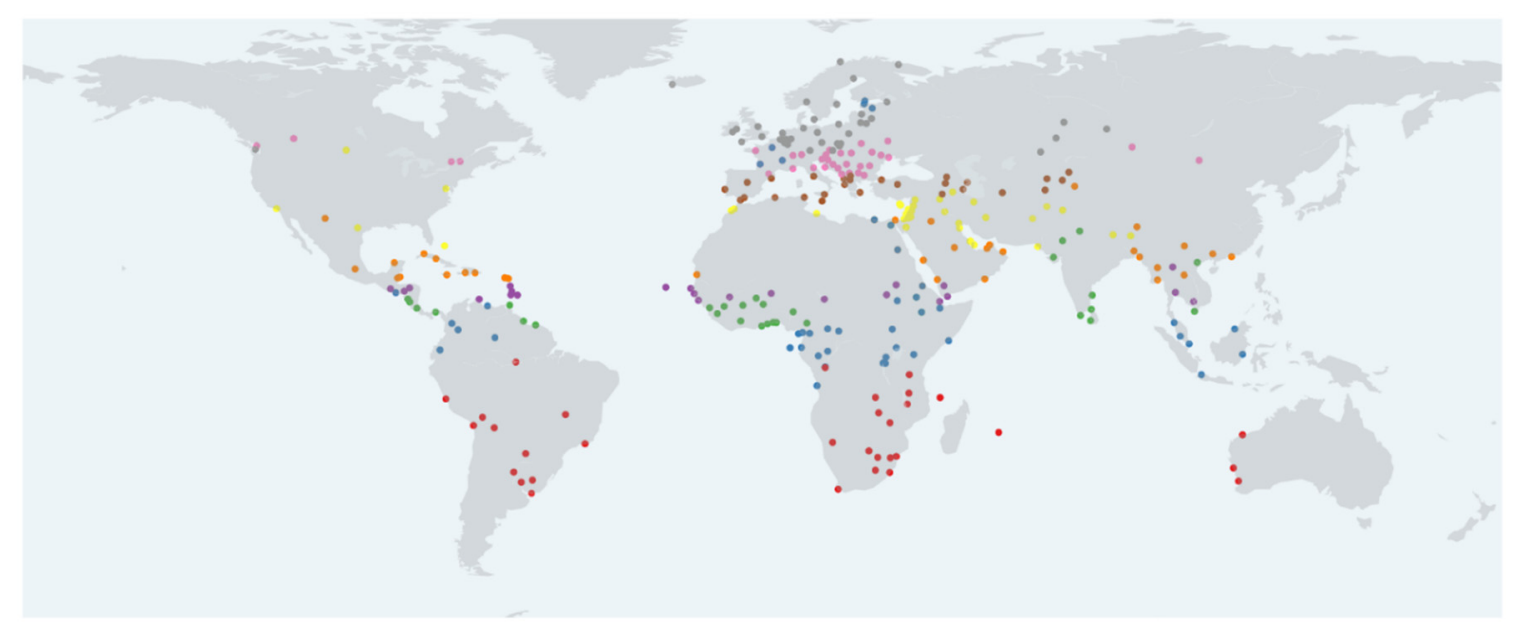

Figure 1. The places where the training data are collected.

In Figure 1, the locations are highlighted by colored circles. The circles' color is separated to give the figure more detail, and they do not mean anything else.

The development of the artificial neural network model is carried out using feed-forward neural networks (FFNN). The development process is divided into the training phase and the testing phase. Figure 2 shows the methodology used to develop the FFNN model. 


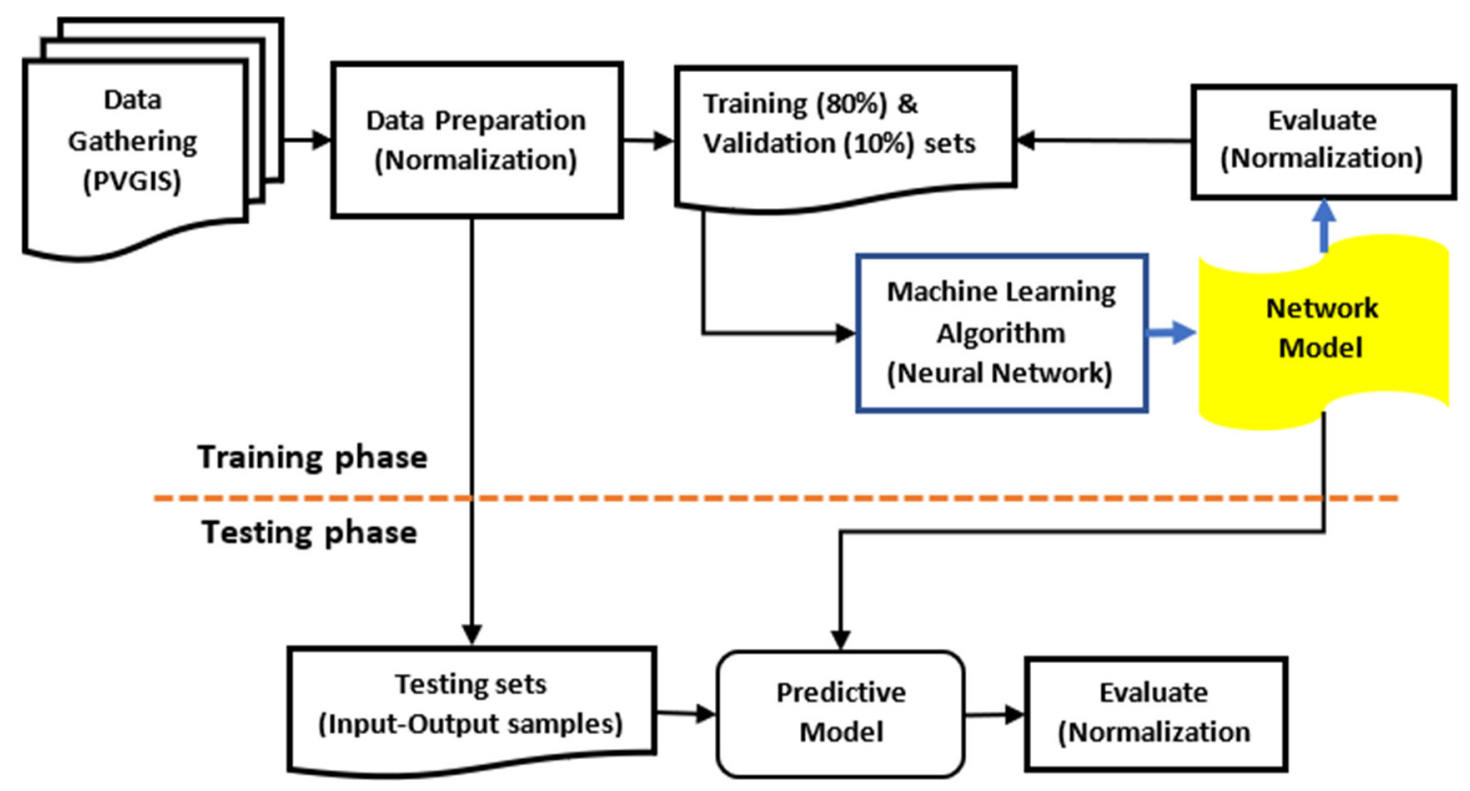

Figure 2. Methodology used to develop the feed-forward neural networks (FFNN) model.

The data collected were normalized and divided into two sets after the correct validation using the PVGIS method. One was used at the development stage of the neural model, representing $90 \%$ of the data collected, and one was used at the neural model test stage, representing around $10 \%$. The testing phase aims to evaluate the neural network model developed in the training phase. The $90 \%$ of the gathered data used in the training phase was further divided into a neural network model training set, about $80 \%$ of the gathered data, and a neural network model validating set, which is about $10 \%$ of the gathered data. After the training phase, a multi-level FFNN model was developed. The developed multi-level FFNN model is discussed in the subsequent section.

\section{Multi-Level Neural Network Model}

Feed-forward neural network (FFNN) is a supervised learning algorithm that learns, by training on a dataset, a function $f():. R^{n} \rightarrow R^{o}$. Where o is the number of dimensions for output, and $\mathrm{n}$ is the number of dimensions for inputs. Given a set of features $X=\left\{x_{1}, x_{2}, \ldots, x_{n}\right\}$ and targets $Y=\left\{y_{1}, y_{2}, \ldots, y_{0}\right\}$, it can learn a non-linear function approximator for either regression or classification problems. In this work, FFNN is used as a regression model, and this differs from logistic regression, as there are one or more non-linear layers, called the hidden layer, which lies between the input and output layers. Figure 3 shows one hidden layer FFNN.

The leftmost layer, known as the input layer, consists of neurons expressing the input patterns, as shown in Figure 3. With a weighted linear summation $\sum_{i=1}^{n} x_{i} w_{i j}$, each neuron in the hidden layer transforms the previous layer's values, which are then evaluated using activation function [54]. Where $w_{i j}$ is the weight relation between the $i$ th neuron in the input layer and the $j$ th neuron in the hidden layer, $x i$ is the value of $i$ th neuron in the input layer. The values are propagated to the neurons of the output layer to generate the output patterns.

Figure 4 shows the topology of the proposed model. The proposed network model predicts the PV's optimum tilt and azimuth angle of annual irradiation in various regions worldwide. 


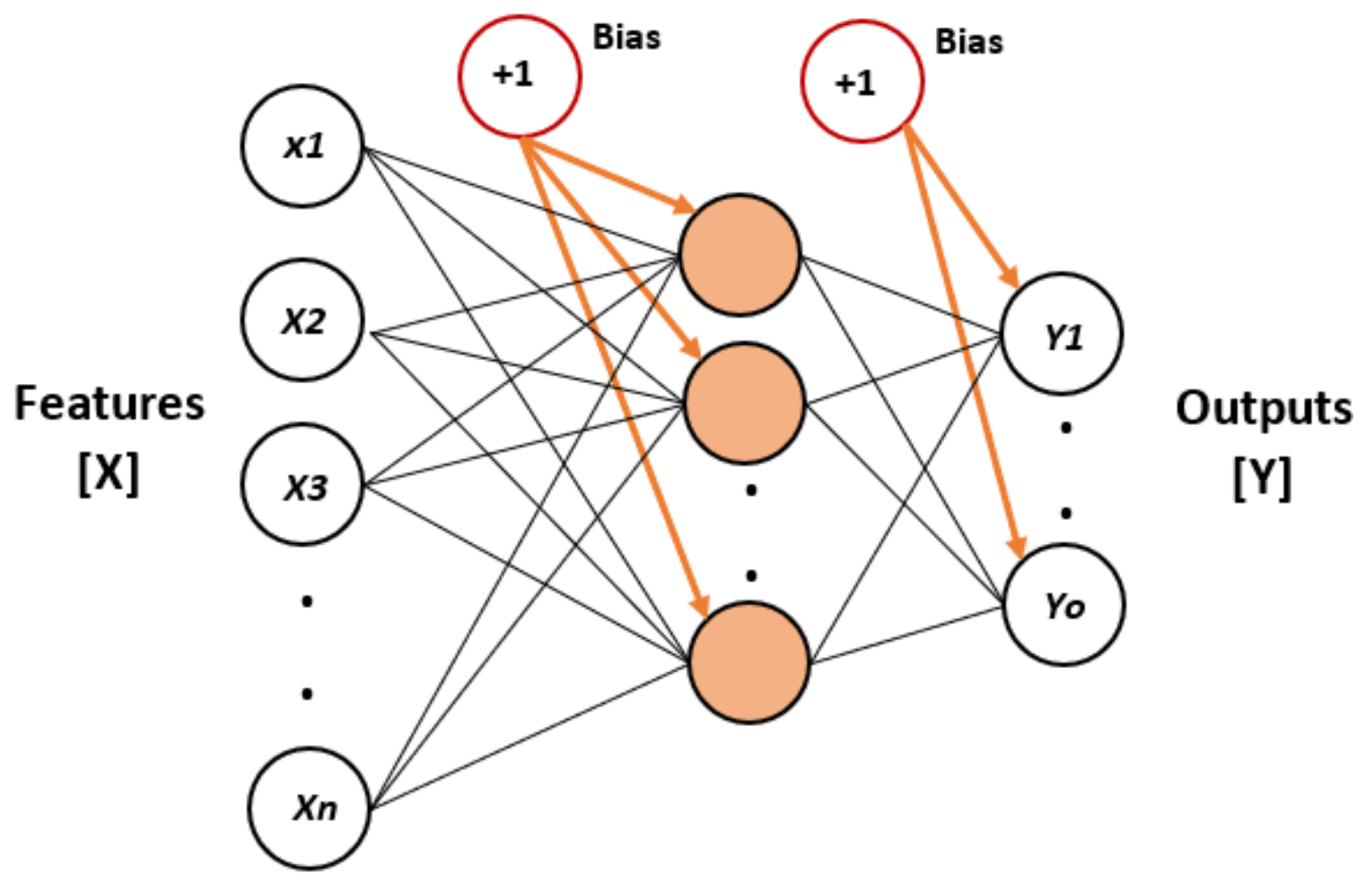

Figure 3. One hidden layer neural network structure.

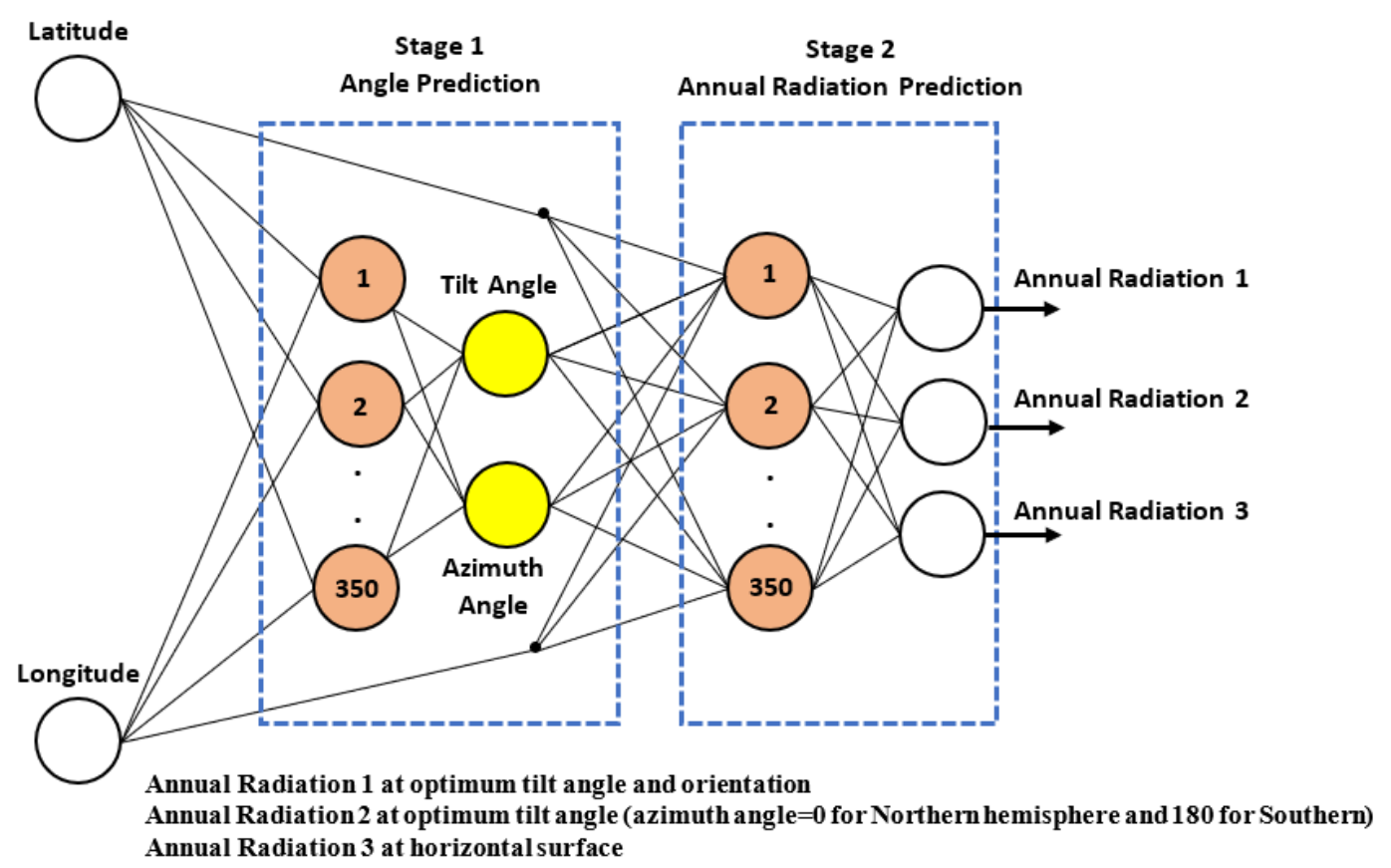

Figure 4. The developed neural network topology.

The proposed model is composed of two phases, as shown in Figure 4. The model consists of three layers in the first stage: Input, Hidden, and Output. Two nodes form the input layer: longitude (deg.) and latitude (deg.). Three hundred fifty nodes compose the hidden layer, each of which uses the activation function of the hyperbolic tangent sigmoid. The output layer consists of two nodes that evaluate the optimal PV's tilt and azimuth angles. 
The second stage's input layer is composed of four nodes, two of them are the outputs of the first stage (tilt and azimuth angles), and the others are the Latitude and the Longitude. The hidden layer is like the first stage; it has 350 nodes with tanh activation function. At the same time, the output layer has three nodes, which are the annual irradiation under (1) optimum tilt angle and orientation (2) optimum tilt angle (azimuth angle $=0$ for the Northern hemisphere and 180 for Southern) (3) horizontal surface. The output nodes in the two stages use an activation function of linear type [49].

Min-Max normalization method is used on all data to improve the qualified network's efficiency [55]. The data are then used to trained the network to understand the relationships between the input patterns.

$$
\begin{aligned}
& I_{N}=\left(I-I_{\text {min }}\right)\left[\frac{N_{\max }-N_{\min }}{I_{\max }-I_{\min }}\right]+N_{\text {min }} \\
& O=\left(O_{N}-N_{\text {min }}\right)\left[\frac{O_{\max }-O_{\min }}{N_{\max }-N_{\min }}\right]+O_{\text {min }}
\end{aligned}
$$

where $N_{\min }$ and $N_{\max }$ are the Min-Max normalize range, $O_{\max }$ and $O_{\min }$ are the maximum and minima values for the $\mathrm{O}$ output vector, $O_{N}$ and $I_{N}$ are the normalized training output and input values, $I_{\max }$ and $I_{\min }$ are the maximum and minima values for the input vector $I$, and $I$ and $O$ are the non-normalized training input and output values. For this work, $N_{\min }=-1$ and $N_{\max }=1$ [56].

Different types of FFNN's trained algorithms were developed [55,57,58]. These include the Gradient descent with momentum approach, the Levenberg-Marquardt (LM) backpropagation, the Gradient descent backpropagation, and the adaptive learning rate resilient scaled conjugate gradient backpropagation. The LM training algorithm has been chosen for this work for the training of the proposed network model. Since the less responsive approach to local converges, the LM teaching method offers a more robust learning training approach. It also offers a healthy trade-off between the pace of preparation and stability [55].

Figure 5 displays the pseudocode for the training algorithm. The goal is to minimize as much as possible, the mean square error (MSE) by tuning the parameter $(\mu)$ as follows:

- $\quad \mu \times 0.1$ when the MSE is equal or less to the previous one.

- $\quad \mu \times 10$ when the current epoch MSE exceeds the previous value. 


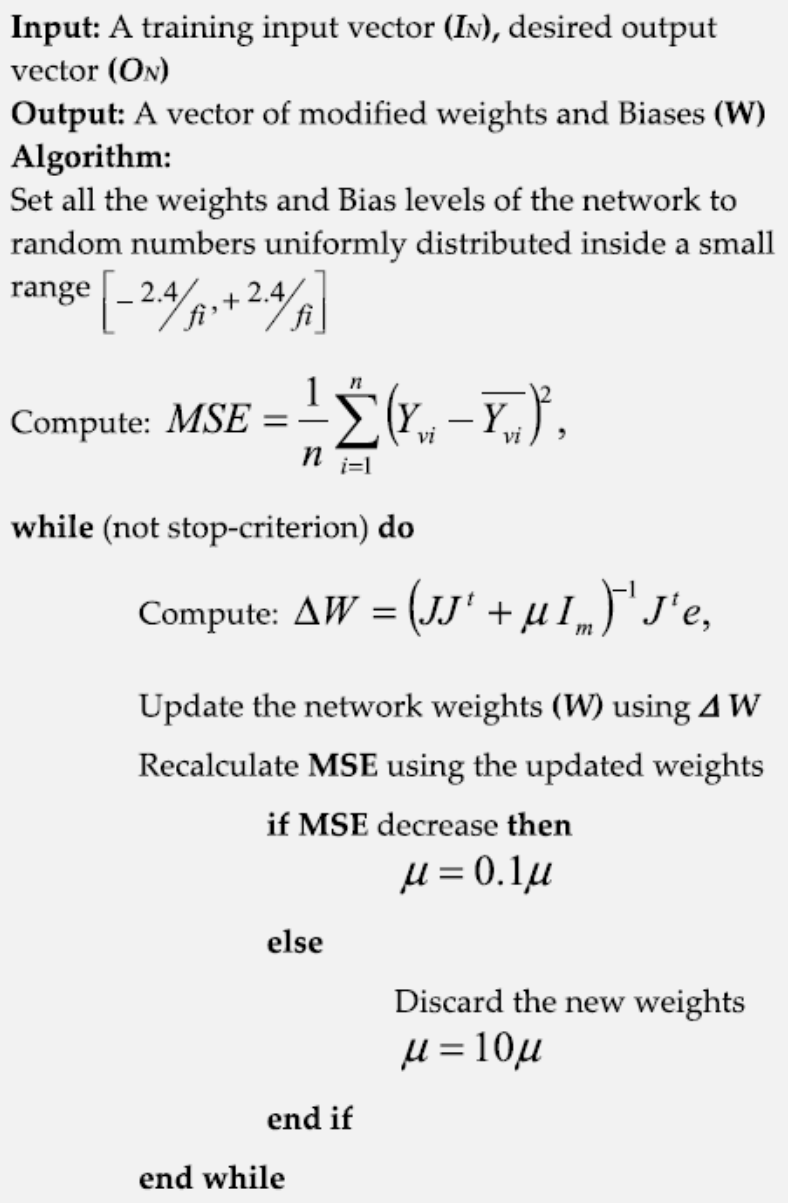

Figure 5. Levenberg Marquardt algorithm.

\section{Results and Discussion}

\subsection{Results Obtained by PVGIS}

In the first part of the paper, PVGIS was used to obtain the results and tabulated in Table A1 (Appendix A). The optimum tilt angles, optimum azimuth angle, AR1, DR1, AR2, DR2, AR3, DR3, and $\mathrm{F}$, are calculated for the different regions worldwide.

It can be concluded that the tilt angle is equal to or greater than the latitude until the latitude of $30^{\circ}$, then the tilt angle becomes less than the latitude until the difference between them reaches more than $20^{\circ}$. The relation between them is not linear for all the latitudes because the linear relationship does not take into account the air pollution and cloud cover. As the cloud cover increases, the optimum tilt angle decreases because the cloud cover scatters the solar irradiation. The solar PV is closer to the horizontal as it receives more of the diffuse solar irradiation that is scattered by the cloud cover. Besides, the direct solar irradiation, which mainly depends on the tilt angle, is mostly blocked by clouds, so the diffuse irradiation becomes more critical in the overcast latitudes. The azimuth or orientation of the solar PV is measured from the south, meaning that if it is directed to the south, then the azimuth angle is $0^{\circ}$, while if it is directed to the north, then the azimuth angle is $180^{\circ}$. For the east, the azimuth is -90 degrees, and for the west, it is 90 degrees. It can be concluded that the optimum azimuth angle for most cities in the northern hemisphere and southern hemisphere is close to $0^{\circ}$ and $180^{\circ}$, respectively. Even cities with an optimum azimuth angle further from $0^{\circ}$ and $180^{\circ}$ gain a little extra annual solar irradiation (AR1-AR2). This means that the solar PV can be directed toward the south in the northern hemisphere and toward the north in the southern hemisphere. 
Table 1 shows that the annual solar irradiation increases as it moves away from the equator until it reaches the maximum point $\left(25-30^{\circ}\right)$ for latitude and then begins to decrease. It can also be noticed that the tilt factor $(F)$ increases with increasing latitude because of the increase in the optimum tilt angle with latitude.

The results obtained from PVGIS are compared with many previous studies and the results are very close $[59,60]$.

\subsection{Evaluation of the Proposed Nural Network Model}

Several experiments have been performed to determine the best composition of the neural network. The decisions were made based on two main features: the activation function for each layer and the neurons' number in the hidden layer. Table 2 shows the attributes of the selected configurations.

Table 2. The parameters of the proposed network models' structures.

\begin{tabular}{|c|c|c|c|}
\hline \multicolumn{2}{|c|}{$\begin{array}{l}\text { Stage } 1 \text { Structure } \\
\text { (Angle Prediction) }\end{array}$} & \multicolumn{2}{|c|}{$\begin{array}{c}\text { Stage } 2 \text { Structure } \\
\text { (Annual Irradiation Prediction) }\end{array}$} \\
\hline Attribute & Choice & Attribute & Choice \\
\hline Number of inputs & 2 & Number of inputs & 4 \\
\hline Number of outputs & 2 & Number of outputs & 3 \\
\hline $\begin{array}{l}\text { The hidden layer } \\
\text { activation function }\end{array}$ & Hyperbolic Tangent & $\begin{array}{l}\text { The hidden layer } \\
\text { activation function }\end{array}$ & Hyperbolic Tangent \\
\hline $\begin{array}{l}\text { Output layer activation } \\
\text { function }\end{array}$ & $\begin{array}{c}\text { Linear } \\
\text { (Regression) }\end{array}$ & $\begin{array}{l}\text { Output layer activation } \\
\text { function }\end{array}$ & $\begin{array}{c}\text { Linear } \\
\text { (Regression) }\end{array}$ \\
\hline $\begin{array}{l}\text { Normalization interval } \\
\text { of the dataset }\end{array}$ & {$[-1,1]$} & $\begin{array}{c}\text { Normalization interval } \\
\text { of the dataset }\end{array}$ & {$[-1,1]$} \\
\hline Training approach & Levenberg-Marquardt & Training approach & Levenberg-Marquardt \\
\hline Error & Mean Squared Error & Error & Mean Squared Error \\
\hline
\end{tabular}

Another important feature that has been studied to complete the neural network structures is the number of nodes in each hidden layer. Table 3 compares the mean square error (MSE) results in various hidden layer numbers for both network stages.

Table 3. The hidden layers number of neurons vs. best-obtained results.

\begin{tabular}{cccccccc}
\hline & \multicolumn{2}{c}{$\begin{array}{c}\text { Stage 1 Structure } \\
\text { (Angle Prediction) }\end{array}$} & & & \multicolumn{2}{c}{$\begin{array}{c}\text { Stage 2 Structure } \\
\text { Irradiation Prediction) }\end{array}$} \\
\hline Nodes & MSE Train & $\begin{array}{c}\text { MSE } \\
\text { Validation }\end{array}$ & MSE Test & $\begin{array}{c}\text { Number } \\
\text { of Nodes }\end{array}$ & MSE Train & $\begin{array}{c}\text { MSE } \\
\text { Validation }\end{array}$ \\
\hline 100 & 12.5169 & 8.3296 & 17.861 & 100 & 50.6192 & 150.9851 & 212.771 \\
150 & 7.8641 & 2.0191 & 11.218 & 150 & 13.8712 & 33.8164 \\
200 & 4.0127 & 1.1729 & 6.071 & 200 & 2.1176 & 3.8155 & 7.931 \\
250 & $3.810 \times 10^{-1}$ & 4.7263 & 5.291 & 250 & $6.1839 \times 10^{-1}$ & 1.0069 \\
300 & $6.211 \times 10^{-2}$ & $2.1058 \times 10^{-1}$ & $8.16 \times 10^{-1}$ & 300 & $2.0174 \times 10^{-2}$ & $5.9816 \times 10^{-2}$ & $7.97 \times 10^{-1}$ \\
350 & $2.527 \times 10^{-2}$ & $1.1688 \times 10^{-3}$ & $4.0 \times 10^{-2}$ & 350 & $7.3972 \times 10^{-3}$ & $1.5783 \times 10^{-4}$ & $6.26 \times 10^{-3}$ \\
400 & $8.875 \times 10^{-2}$ & $4.6688 \times 10^{-2}$ & $1.94 \times 10^{-1}$ & 400 & $2.9261 \times 10^{-3}$ & $7.2705 \times 10^{-3}$ & $7.91 \times 10^{-2}$ \\
$300 \times 300$ & $2.1197 \times 10^{-2}$ & $8.9912 \times 10^{-1}$ & 1.368 & $300 \times 300$ & $4.2281 \times 10^{-1}$ & $2.8861 \times 10^{-1}$ & 1.891 \\
$350 \times 350$ & $7.9712 \times 10^{-1}$ & $9.1862 \times 10^{-1}$ & 2.261 & $350 \times 350$ & $8.6691 \times 10^{-2}$ & $7.6331 \times 10^{-1}$ & 3.225 \\
\hline
\end{tabular}

The best-obtained configuration for models' stages 1 and 2 is 350 neurons the hidden layer, seen in Table 3. MSE for both first stage preparation, checking, and validation is $0.0253,0.041$, and 0.00117 , respectively, and for the second stage is $0.0074,0.0063$, and 0.00016 , respectively. However, the results did not get any higher, while the sophistication grew as we went to the deep neural network.

Once the network configuration was chosen and before the simulation started, the dataset of 573 cities was split into three sections: training (459 cases), validation (57 cases), and testing (57 cases) (57 cases). The dataset has been chosen in a way that covers the maximum possible area, according to 
the map shown in Figure 1. Using the early stop technique and the validation set [61], the overfitting was reduced. Figure 6 demonstrates the consequences of both systems during training and validation.

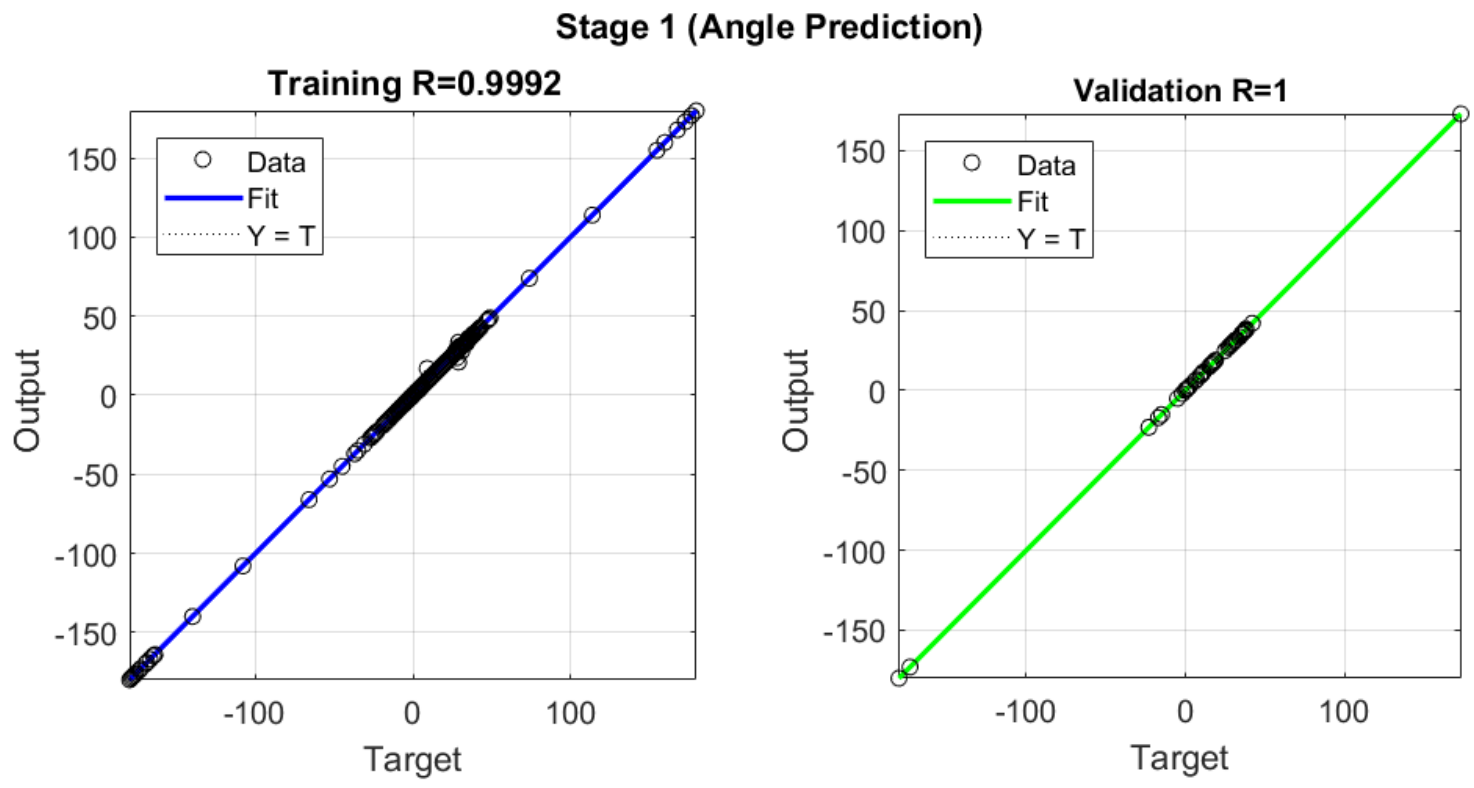

Stage 2 (Annual Radiation Prediction)
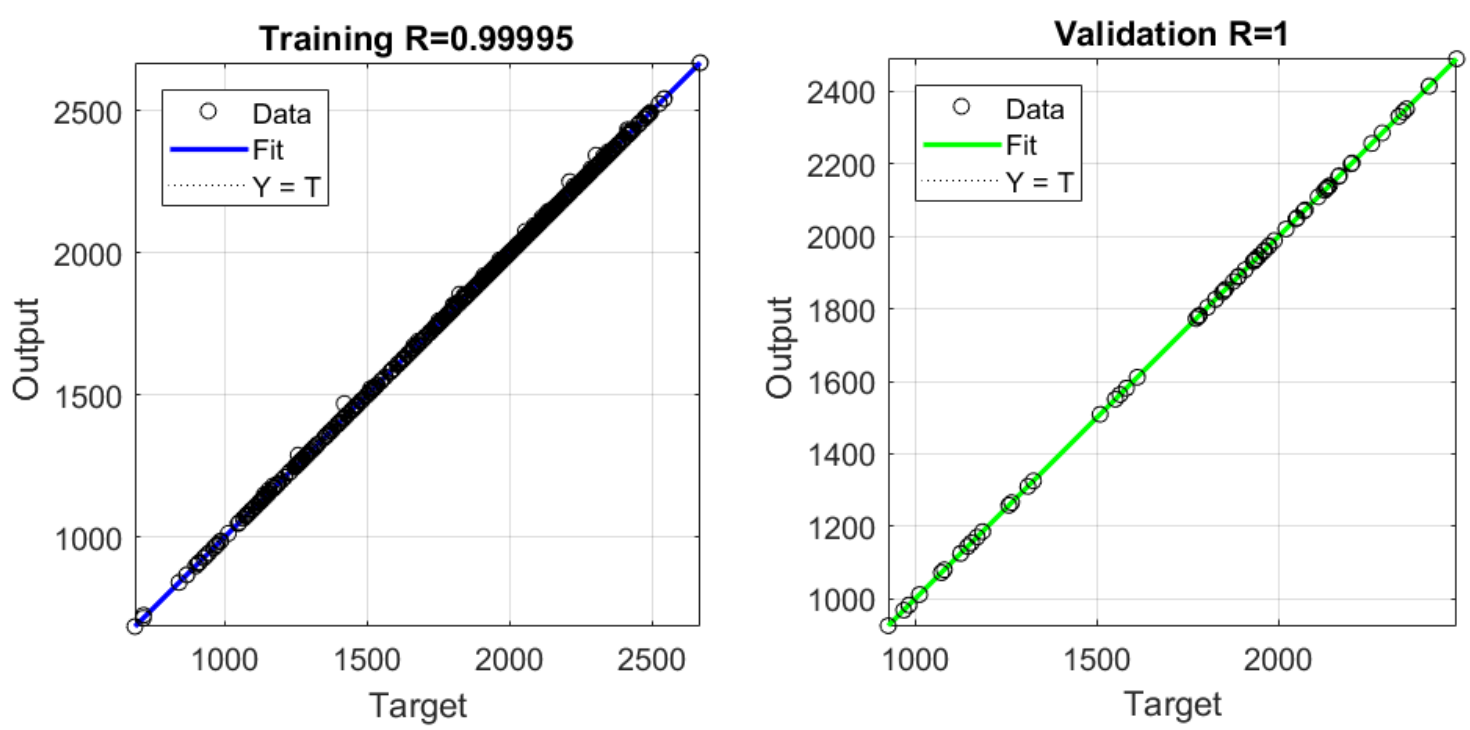

Figure 6. Regression of error for both stage 1 and 2 networks model.

As shown Figure 6, the linear regression for the training and validation of both models exactly matches the data sets, which means that the decision coefficient (R2) is very similar to 1.

The testing dataset portion was used to assess the model, and then measure the output after the training stage is finished.

Table A2 (Appendix A) shows a comparison between the calculated model using PVGIS and the proposed model. The comparison has been made regarding 40 cities (30 in-sample and ten out-of-sample). As shown in Table A2 (Appendix A), the residual average difference (between the calculated and proposed model) for the tilt angle, azimuth angle, and the three annual irradiations (see Figure 4 ) is $0.0234,-0.0224,0.136,1.41,0.264$, respectively. That comparison demonstrates the effectiveness of the proposed model. 


\section{Conclusions}

The solar energy incident on a PV depends of the tilt angle and orientation. Therefore, they considered a vital factor to obtain maximum solar radiation. It can be concluded that in most cases in the northern hemisphere, solar PV must be directed toward the south, this means that the azimuth angle is equal to zero. Whereas for the southern hemisphere, the solar panels must be directed toward the north, which means that the azimuth angle is equal to 180. So AR1 and AR2 are almost the same for most cities. In general, as the latitude of a specific city increases, it benefits from tilting increases, So the tilt factor increases with increasing latitude.

Neural networks are distinguished by being able to learn and generate an output of their own that is not limited to the feedback they receive. In addition, the network will detect the fault and still generate the output, even though a neuron is not responding, or a piece of information is missing. Therefore, the purpose of this research is to create a simple neural network model that can reliably predict the annual radiation and optimum tilt and azimuth angle in any area of the world and can be easily implemented in a low-cost microcontroller.

It can be concluded that the tilt angle is about or greater than the latitude until the latitude of $30^{\circ}$, then it becomes less than the latitude until the difference between them reaches more than $20^{\circ}$. The relation between them is not linear for all the latitudes.

Moreover, this study presents a multi-level world comprehensive neural network model for annual irradiation and PV optimum azimuth and tilt angles. Several simulations were carried out with different evaluation criteria to select the best network topology.

The proposed network topology is composed of two stages. The first stage is to predict the PV optimum tilt and azimuth angle, and the second stage is to predict the AR1, AR2, and AR3. The simulation result shows that the proposed module exhibits excellent performance with an average training MSE of 0.01635 . This proposed model can be used in an embedded system or an online system for further PV system analysis and optimization.

Author Contributions: Conceptualization, R.A. A.J. E.N., and S.S.; methodology, R.A., A.J., E.N., and S.S.; software, R.A. and E.N.; validation, A.J., R.A., E.N., and S.S.; formal analysis, E.N. and A.J.; investigation, R.A., A.J., and F.M.-A; writing-original draft preparation, R.A., A.J., E.N., and S.S.; writing-review and editing, F.M.-A., A.J., and S.S. All authors have read and agreed to the published version of the manuscript.

Funding: This research received no external funding.

Acknowledgments: The authors would like to acknowledge the: An-Najah National University and the University of Almeria for facilitating this research.

Conflicts of Interest: The authors declare no conflict of interest.

\begin{tabular}{|c|c|}
\hline \multicolumn{2}{|c|}{ Abbreviations } \\
\hline AR1 & Annual Irradiation $\left(\mathrm{kWh} / \mathrm{m}^{2}\right)$ at optimum tilt angle and orientation \\
\hline AR2 & $\begin{array}{l}\text { Annual Irradiation }\left(\mathrm{kWh} / \mathrm{m}^{2}\right) \text { at optimum tilt angle (azimuth angle }=0^{\circ} \text { for Northern } \\
\text { hemisphere and } 180^{\circ} \text { for Southern) }\end{array}$ \\
\hline AR3 & Annual Irradiation $\left(\mathrm{kWh} / \mathrm{m}^{2}\right)$ at horizontal surface \\
\hline CMSAF & Climate Monitoring Satellite Application Facility \\
\hline DR1 & Daily Average Irradiation $\left(\mathrm{kWh} / \mathrm{m}^{2} /\right.$ day $)$ at optimum tilt angle and orientation \\
\hline DR2 & $\begin{array}{l}\text { Daily Average Irradiation }\left(\mathrm{kWh} / \mathrm{m}^{2} / \text { day) at optimum tilt angle (azimuth angle }=0^{\circ} \text { for }\right. \\
\text { Northern hemisphere and } 180^{\circ} \text { for Southern) }\end{array}$ \\
\hline DR3 & Daily Average Irradiation $\left(\mathrm{kWh} / \mathrm{m}^{2} /\right.$ day) at horizontal surface \\
\hline ECMWF & European Centre for Medium-Range Weather Forecasts \\
\hline $\mathrm{F}$ & The tilt factor \\
\hline MSE & Mean Square Error \\
\hline NREL & National Solar Irradiation Database \\
\hline PSO & Particle Swarm Optimization \\
\hline PV & Photovoltaic \\
\hline
\end{tabular}


PVGIS Photovoltaic Geographical Information System

SDGs Sustainable Development Goals

$\beta \quad$ Tilt angle (Degrees)

FFNN Feed-Forward Neural Networks

LM Levenberg-Marquardt

AR1 Annual Irradiation $\left(\mathrm{kWh} / \mathrm{m}^{2}\right)$ at optimum tilt angle and orientation

AR2

Annual Irradiation $\left(\mathrm{kWh} / \mathrm{m}^{2}\right)$ at optimum tilt angle (azimuth angle $=0$ for Northern

hemisphere and 180 for Southern)

AR3 Annual Irradiation $\left(\mathrm{kWh} / \mathrm{m}^{2}\right)$ at horizontal surface

DR1 Daily Average Irradiation $\left(\mathrm{kWh} / \mathrm{m}^{2} /\right.$ day) at optimum tilt angle and orientation

DR2 Daily Average Irradiation $\left(\mathrm{kWh} / \mathrm{m}^{2} /\right.$ day) at optimum tilt angle (azimuth angle $=0$ for

Northern hemisphere and 180 for Southern)

DR3 Daily Average Irradiation $\left(\mathrm{kWh} / \mathrm{m}^{2} /\right.$ day) at horizontal surface. 


\section{Appendix A}

Table A1. Optimum tilt and azimuth angles for PV panels, AR1, AR2, AR3, DR1, DR2, and DR3 for all countries of the world.

\begin{tabular}{|c|c|c|c|c|c|c|c|c|c|c|c|c|}
\hline Country & City & $\begin{array}{l}\text { Latitude } \\
\text { (deg.) }\end{array}$ & $\begin{array}{c}\text { Longitude } \\
\text { (deg.) }\end{array}$ & $\begin{array}{l}\text { Optimum } \\
\text { Tilt Angle } \\
\text { (deg.) }\end{array}$ & $\begin{array}{l}\text { Azimuth } \\
\text { Angle } \\
\text { (deg.) }\end{array}$ & $\begin{array}{c}\text { AR1 } \\
\left(\mathrm{kWh} / \mathrm{m}^{2}\right)\end{array}$ & $\begin{array}{c}\text { DR1 } \\
\left(\mathrm{kWh} / \mathrm{m}^{2}\right)\end{array}$ & $\begin{array}{c}\text { AR2 } \\
\left(\mathrm{kWh} / \mathrm{m}^{2}\right)\end{array}$ & $\begin{array}{c}\mathrm{DR2} \\
\left(\mathrm{kWh} / \mathrm{m}^{2}\right)\end{array}$ & $\begin{array}{c}\text { AR3 } \\
\left(\mathrm{kWh} / \mathrm{m}^{2}\right)\end{array}$ & $\begin{array}{c}\text { DR3 } \\
\left(\mathrm{kWh} / \mathrm{m}^{2}\right)\end{array}$ & $\begin{array}{c}F \\
\text { (Tilt Factor) }\end{array}$ \\
\hline Iceland & Reykjavík & 64.15 & -21.94 & 49 & 0 & 1093.00 & 2.99 & 1093.00 & 2.99 & 839.15 & 2.30 & 1.30 \\
\hline Afghanistan & Kandahar & 31.63 & 65.74 & 30 & -2 & 2418.44 & 6.63 & 2418.29 & 6.63 & 2166.78 & 5.94 & 1.12 \\
\hline Afghanistan & Kabul & 34.56 & 69.21 & 31 & -8 & 2228.34 & 6.11 & 2226.44 & 6.10 & 1981.05 & 5.43 & 1.12 \\
\hline Albania & Tirana & 41.33 & 19.82 & 35 & -2 & 1835.59 & 5.03 & 1835.37 & 5.03 & 1581.86 & 4.33 & 1.16 \\
\hline Albania & Sarande & 39.87 & 20.00 & 33 & 2 & 1939.22 & 5.31 & 1939.00 & 5.31 & 1694.53 & 4.64 & 1.14 \\
\hline Algeria & Algiers & 36.75 & 3.06 & 31 & -4 & 2014.21 & 5.52 & 2013.71 & 5.52 & 1788.61 & 4.90 & 1.13 \\
\hline Andorra & Andorra La Vella & 42.51 & 1.52 & $35(34)$ & -18 & 1644.99 & 4.51 & 1627.00 & 4.46 & 1418.10 & 3.89 & 1.15 \\
\hline Angola & Luanda & -8.84 & 13.29 & 9 & -179 & 1988.58 & 5.45 & 1988.57 & 5.45 & 1972.00 & 5.40 & 1.01 \\
\hline Antigua and Barbuda & St. Johns & 17.12 & -61.84 & 19(18) & -17 & 2164.31 & 5.93 & 2158.43 & 5.91 & 2080.39 & 5.70 & 1.04 \\
\hline Argentina & Entre Rios & -32.23 & -58.69 & 30 & -169 & 1896.28 & 5.20 & 1895.30 & 5.19 & 1721.98 & 4.72 & 1.10 \\
\hline Argentina & Santa Fe & -29.77 & -60.51 & 28 & -169 & 1917.10 & 5.25 & 1915.26 & 5.25 & 1760.64 & 4.82 & 1.09 \\
\hline Armenia & Yerevan & 40.19 & 44.52 & 33 & -6 & 1826.76 & 5.00 & 1826.36 & 5.00 & 1611.18 & 4.41 & 1.13 \\
\hline Australia & Perth & -31.95 & 115.86 & 29 & -176 & 2165.87 & 5.93 & 2165.50 & 5.93 & 1965.62 & 5.39 & 1.10 \\
\hline Australia & Geraldton & -28.78 & 114.61 & 28 & -180 & 2301.10 & 6.30 & 2301.10 & 6.30 & 2092.13 & 5.73 & 1.10 \\
\hline Australia & Karratha & -20.73 & 116.84 & 23 & -180 & 2490.05 & 6.82 & 2490.05 & 6.82 & 2343.49 & 6.42 & 1.06 \\
\hline Austria & Vienna & 48.21 & 16.37 & 38 & 0 & 1430.94 & 3.92 & 1430.94 & 3.92 & 1224.67 & 3.36 & 1.17 \\
\hline Austria & Graz & 47.07 & 15.44 & 39 & -2 & 1503.00 & 4.12 & 1502.85 & 4.12 & 1270.51 & 3.48 & 1.18 \\
\hline Azerbaijan & Baku & 40.41 & 49.87 & 32 & 5 & 1663.83 & 4.56 & 1663.05 & 4.56 & 1495.81 & 4.10 & 1.11 \\
\hline Azerbaijan & Lankaran & 38.75 & 48.85 & 31 & 2 & 1678.76 & 4.60 & 1678.55 & 4.60 & 1514.72 & 4.15 & 1.11 \\
\hline Bahamas & Nassau & 25.05 & -77.36 & 25 & -5 & 2104.47 & 5.77 & 2104.42 & 5.77 & 1958.65 & 5.37 & 1.07 \\
\hline Bahrain & Manama & 26.22 & 50.59 & 26 & -1 & 2404.04 & 6.59 & 2404.00 & 6.59 & 2230.98 & 6.11 & 1.08 \\
\hline Bahrain & Riffa & 26.13 & 50.54 & 26 & -1 & 2416.54 & 6.62 & 2416.48 & 6.62 & 2245.62 & 6.15 & 1.08 \\
\hline Bangladesh & Dhaka & 23.81 & 90.41 & 28 & 4 & 1916.26 & 5.25 & 1915.32 & 5.25 & 1759.41 & 4.82 & 1.09 \\
\hline Bangladesh & Chittagong & 22.36 & 91.78 & 27 & 8 & 2036.81 & 5.58 & 2034.05 & 5.57 & 1872.39 & 5.13 & 1.09 \\
\hline
\end{tabular}


Table A1. Cont.

\begin{tabular}{|c|c|c|c|c|c|c|c|c|c|c|c|c|}
\hline Barbados & Bridgetown & 13.11 & -59.61 & 15 & -27 & 2107.36 & 5.77 & 2098.29 & 5.75 & 2058.16 & 5.64 & 1.02 \\
\hline Belgium & Brussels & 50.85 & 4.35 & 39 & 0 & 1258.11 & 3.45 & 1258.11 & 3.45 & 1076.91 & 2.95 & 1.17 \\
\hline Belgium & Saint Hubert & 50.03 & 5.37 & 36 & 0 & 1198.90 & 3.28 & 1198.90 & 3.28 & 1049.61 & 2.88 & 1.14 \\
\hline Belize & Belmopan & 17.25 & -88.76 & 17 & 7 & 1907.61 & 5.23 & 1906.68 & 5.22 & 1850.78 & 5.07 & 1.03 \\
\hline Belize & Belize City & 17.50 & -88.20 & 18 & 4 & 2056.07 & 5.63 & 2055.63 & 5.63 & 1983.43 & 5.43 & 1.04 \\
\hline Benin & Port Novo & 6.50 & 2.63 & 11 & 27 & 1932.30 & 5.29 & 1927.88 & 5.28 & 1906.39 & 5.22 & 1.01 \\
\hline Bhutan & Thimphu & 27.47 & 89.63 & 31 & -15 & 1913.66 & 5.24 & 1902.28 & 5.21 & 1704.45 & 4.67 & 1.12 \\
\hline Bolivia & Sucre & -19.04 & -65.26 & 23 & -180 & 2433.17 & 6.67 & 2433.17 & 6.67 & 2280.76 & 6.25 & 1.07 \\
\hline Bolivia & $\mathrm{LaPaz}$ & -16.49 & -68.12 & 21 & -180 & 2285.57 & 6.26 & 2285.57 & 6.26 & 2165.62 & 5.93 & 1.06 \\
\hline Bosnia Herzegovina & Sarajevo & 43.86 & 18.41 & 34 & -5 & 1431.11 & 3.92 & 1430.05 & 3.92 & 1258.74 & 3.45 & 1.14 \\
\hline Bosnia Herzegovina & Banja Luka & 44.77 & 17.19 & 35 & -4 & 1458.17 & 3.99 & 1457.45 & 3.99 & 1274.61 & 3.49 & 1.14 \\
\hline Botswana & Gaborone & -24.63 & 25.92 & 29 & -180 & 2352.15 & 6.44 & 2352.15 & 6.44 & 2135.01 & 5.85 & 1.10 \\
\hline Brazil & Brasilia & -15.83 & -47.92 & 23 & -180 & 2112.59 & 5.79 & 2112.59 & 5.79 & 1997.21 & 5.47 & 1.06 \\
\hline Brazil & Rio De Janeiro & -22.91 & -43.17 & 24 & -180 & 1872.95 & 5.13 & 1872.95 & 5.13 & 1755.27 & 4.81 & 1.07 \\
\hline Brazil & Manaus & -3.12 & -60.02 & 7 & -180 & 1780.18 & 4.88 & 1780.18 & 4.88 & 1772.99 & 4.86 & 1.00 \\
\hline Brunei Darussalam & $\begin{array}{c}\text { Bandar Seri } \\
\text { Begawan }\end{array}$ & 4.90 & 114.94 & 5 & 47 & 1849.17 & 5.07 & 1845.30 & 5.06 & 1841.85 & 5.05 & 1.00 \\
\hline Bulgaria & Sofia & 42.70 & 23.32 & 35 & -4 & 1605.33 & 4.40 & 1605.16 & 4.40 & 1404.10 & 3.85 & 1.14 \\
\hline Bulgaria & Plovdiv & 42.14 & 24.75 & 35 & 0 & 1701.22 & 4.66 & 1701.22 & 4.66 & 1479.08 & 4.05 & 1.15 \\
\hline Burkina Faso & Ouagadougou & 12.37 & -1.52 & 16 & 0 & 2356.42 & 6.46 & 2356.42 & 6.46 & 2282.11 & 6.25 & 1.03 \\
\hline Burkina Faso & Banfora & 10.64 & -4.76 & 15 & 1 & 2274.34 & 6.23 & 2274.07 & 6.23 & 2214.97 & 6.07 & 1.03 \\
\hline Burundi & Gitega & -3.43 & 29.92 & 7 & -180 & 1903.71 & 5.22 & 1903.71 & 5.22 & 1893.34 & 5.19 & 1.01 \\
\hline Burundi & Bujumbura & -3.36 & 29.36 & 8 & -180 & 1982.06 & 5.43 & 1982.06 & 5.43 & 1970.43 & 5.40 & 1.01 \\
\hline Cabo Verde & Praia & 15.00 & -23.51 & 15 & 3 & 2263.18 & 6.20 & 2262.90 & 6.20 & 2205.96 & 6.04 & 1.03 \\
\hline Cambodia & Phnom Penh & 11.56 & 104.93 & 14 & 0 & 1932.87 & 5.30 & 1932.87 & 5.30 & 1893.75 & 5.19 & 1.02 \\
\hline Cameroon & Yaounde & 3.85 & 11.50 & 7 & 35 & 1882.09 & 5.16 & 1877.84 & 5.14 & 1867.71 & 5.12 & 1.01 \\
\hline Cameroon & Douala & 4.05 & 9.77 & 12 & 43 & 1784.62 & 4.89 & 1772.88 & 4.86 & 1762.26 & 4.83 & 1.01 \\
\hline Canada & Ottawa & 45.42 & -75.70 & 37 & 0 & 1563.56 & 4.28 & 1563.56 & 4.28 & 1325.33 & 3.63 & 1.18 \\
\hline Canada & Montreal & 45.50 & -73.57 & 37 & 5 & 1535.22 & 4.21 & 1533.93 & 4.20 & 1302.97 & 3.57 & 1.18 \\
\hline
\end{tabular}


Table A1. Cont.

\begin{tabular}{|c|c|c|c|c|c|c|c|c|c|c|c|c|}
\hline Canada & Calgary & 51.04 & -114.07 & 43 & -4 & 1592.94 & 4.36 & 1592.13 & 4.36 & 1268.46 & 3.48 & 1.26 \\
\hline Canada & Vancouver & 49.28 & -123.12 & 38 & 6 & 1403.44 & 3.85 & 1401.30 & 3.84 & 1186.43 & 3.25 & 1.18 \\
\hline Central Afr. Republic & Bangui & 4.39 & 18.56 & 8 & 21 & 2037.03 & 5.58 & 2034.98 & 5.58 & 2021.71 & 5.54 & 1.01 \\
\hline Central Afr. Republic & Carnot & 4.94 & 15.88 & 10 & 25 & 2073.25 & 5.68 & 2069.33 & 5.67 & 2051.33 & 5.62 & 1.01 \\
\hline Chad & N’Djamena & 12.13 & 15.06 & 17 & 2 & 2402.55 & 6.58 & 2402.16 & 6.58 & 2323.50 & 6.37 & 1.03 \\
\hline Chile & Arica & -18.48 & -70.31 & 18 & -180 & 2274.32 & 6.23 & 2274.32 & 6.23 & 2193.16 & 6.01 & 1.04 \\
\hline China & Guigang & 23.11 & 109.60 & 19 & 17 & 1400.07 & 3.84 & 1396.45 & 3.83 & 1354.50 & 3.71 & 1.03 \\
\hline China & Kashgar & 39.47 & 75.99 & 36 & 2 & 2009.22 & 5.50 & 2008.93 & 5.50 & 1720.53 & 4.71 & 1.17 \\
\hline China & Lhasa & 29.65 & 91.14 & 35 & -4 & 2305.73 & 6.32 & 2304.28 & 6.31 & 1992.22 & 5.46 & 1.16 \\
\hline China & Kunming & 25.02 & 102.68 & 28 & 4 & 1745.82 & 4.78 & 1745.04 & 4.78 & 1605.72 & 4.40 & 1.09 \\
\hline Colombia & Bogota & 4.71 & -74.07 & 6 & 0 & 1684.99 & 4.62 & 1684.99 & 4.62 & 1678.45 & 4.60 & 1.00 \\
\hline Colombia & Medellin & 6.254 & -75.576 & 5 & -8 & 1896.07 & 5.19 & 1895.95 & 5.19 & 1890.18 & 5.18 & 1.00 \\
\hline Comoros & Moroni & -11.72 & 43.25 & 13 & -140 & 1892.52 & 5.18 & 1877.10 & 5.14 & 1846.07 & 5.06 & 1.02 \\
\hline $\begin{array}{l}\text { Republic of the } \\
\text { Congo }\end{array}$ & Brazzaville & -4.27 & 15.28 & 4 & -180 & 1877.58 & 5.14 & 1877.58 & 5.14 & 1874.81 & 5.14 & 1.00 \\
\hline $\begin{array}{l}\text { Republic of the } \\
\text { Congo }\end{array}$ & Owando & -0.48 & 15.89 & 0 & -180 & 1924.80 & 5.27 & 1924.80 & 5.27 & 1924.80 & 5.27 & 1.00 \\
\hline $\begin{array}{l}\text { Democratic Republic } \\
\text { of the Congo }\end{array}$ & Kinshasa & -4.44 & 15.27 & 5 & -180 & 1841.02 & 5.04 & 1841.02 & 5.04 & 1837.45 & 5.03 & 1.00 \\
\hline $\begin{array}{l}\text { Democratic Republic } \\
\text { of the Congo }\end{array}$ & Lubumbashi & -11.69 & 27.50 & 19 & -180 & 2286.65 & 6.26 & 2286.65 & 6.26 & 2195.55 & 6.02 & 1.04 \\
\hline Costa-Rica & San José & 9.93 & -84.09 & 14 & -45 & 1933.00 & 5.30 & 1908.08 & 5.23 & 1875.87 & 5.14 & 1.02 \\
\hline Croatia & Zagreb & 45.82 & 15.98 & 35 & 2 & 1511.78 & 4.14 & 1511.63 & 4.14 & 1311.44 & 3.59 & 1.15 \\
\hline Croatia & Zadar & 44.12 & 15.23 & 37 & 2 & 1801.18 & 4.93 & 1801.08 & 4.93 & 1530.99 & 4.19 & 1.18 \\
\hline Cuba & Havana & 23.11 & -82.37 & 23 & -11 & 2094.01 & 5.74 & 2089.25 & 5.72 & 1965.96 & 5.39 & 1.06 \\
\hline Cuba & Sancti Spiritus & 21.93 & -79.44 & 23 & -19 & 2113.43 & 5.79 & 2102.92 & 5.76 & 1982.22 & 5.43 & 1.06 \\
\hline Cyprus & Nicosia & 35.19 & 33.38 & 31 & -2 & 2167.72 & 5.94 & 2167.36 & 5.94 & 1928.19 & 5.28 & 1.12 \\
\hline Cyprus & Larnaca & 34.90 & 33.62 & 31 & 1 & 2164.18 & 5.93 & 2164.12 & 5.93 & 1929.96 & 5.29 & 1.12 \\
\hline Czech Republic & Prague & 50.08 & 14.44 & 37 & -1 & 1317.92 & 3.61 & 1317.88 & 3.61 & 1132.38 & 3.10 & 1.16 \\
\hline Czech Republic & Ostrava & 49.82 & 18.26 & 38 & -1 & 1292.84 & 3.54 & 1292.75 & 3.54 & 1105.96 & 3.03 & 1.17 \\
\hline Denmark & Copenhagen & 55.69 & 12.59 & 40 & 2 & 1261.85 & 3.46 & 1261.65 & 3.46 & 1050.72 & 2.88 & 1.20 \\
\hline
\end{tabular}


Table A1. Cont.

\begin{tabular}{|c|c|c|c|c|c|c|c|c|c|c|c|c|}
\hline Djibouti & Djibouti City & 11.57 & 43.15 & 14 & 11 & 2383.11 & 6.53 & 2381.31 & 6.52 & 2333.55 & 6.39 & 1.02 \\
\hline Dominica & Roseau & 15.31 & -61.38 & 15 & 2 & 1915.78 & 5.25 & 1915.71 & 5.25 & 1875.46 & 5.14 & 1.02 \\
\hline Dominican Republic & Santo Domingo & 18.49 & -69.93 & 20 & -13 & 2084.80 & 5.71 & 2080.37 & 5.70 & 1989.93 & 5.45 & 1.05 \\
\hline Dutch-Antilles & Willemstad & 12.11 & -68.93 & 12 & 7 & 2208.67 & 6.05 & 2208.21 & 6.05 & 2171.92 & 5.95 & 1.02 \\
\hline Ecuador & Quito & -0.18 & -78.47 & 3 & -108 & 1959.69 & 5.37 & 1952.43 & 5.35 & 1950.98 & 5.35 & 1.00 \\
\hline Egypt & Cairo & 30.04 & 31.24 & 28 & 7 & 2417.65 & 6.62 & 2416.13 & 6.62 & 2197.43 & 6.02 & 1.10 \\
\hline Egypt & Port Said & 31.26 & 32.31 & 29 & 3 & 2316.73 & 6.35 & 2314.47 & 6.34 & 2093.57 & 5.74 & 1.11 \\
\hline Egypt & Aswan & 24.09 & 32.90 & 25 & 4 & 2669.99 & 7.32 & 2669.07 & 7.31 & 2471.27 & 6.77 & 1.08 \\
\hline Egypt & Marsa Matruh & 31.35 & 27.24 & 27 & 6 & 2351.08 & 6.44 & 2348.95 & 6.44 & 2150.14 & 5.89 & 1.09 \\
\hline El Salvador & San Salvador & 13.69 & -89.22 & 18 & -18 & 2242.27 & 6.14 & 2235.02 & 6.12 & 2160.75 & 5.92 & 1.03 \\
\hline Equatorial Guinea & Malabo & 3.76 & 8.78 & 8 & 19 & 1676.42 & 4.59 & 1675.38 & 4.59 & 1664.01 & 4.56 & 1.01 \\
\hline Eritrea & Asmara & 15.33 & 38.93 & 20 & 0 & 2339.85 & 6.41 & 2339.85 & 6.41 & 2236.93 & 6.13 & 1.05 \\
\hline Estonia & Tallinn & 59.44 & 24.75 & 41 & 1 & 1119.41 & 3.07 & 1119.31 & 3.07 & 932.40 & 2.55 & 1.20 \\
\hline Estonia & Tartu & 58.38 & 26.73 & 41 & 0 & 1124.62 & 3.08 & 1124.62 & 3.08 & 943.57 & 2.59 & 1.19 \\
\hline Ethiopia & Addis Ababa & 8.97 & 38.73 & 15 & -2 & 2173.71 & 5.96 & 2173.62 & 5.96 & 2118.91 & 5.81 & 1.03 \\
\hline Ethiopia & Gondar & 12.60 & 37.45 & 19 & -26 & 2145.84 & 5.88 & 2130.39 & 5.84 & 2054.75 & 5.63 & 1.04 \\
\hline Finland & Helsinki & 60.17 & 24.94 & 42 & 3 & 1125.27 & 3.08 & 1124.86 & 3.08 & 925.59 & 2.54 & 1.22 \\
\hline France & Paris & 48.85 & 2.35 & 38 & -3 & 1381.32 & 3.78 & 1380.65 & 3.78 & 1181.09 & 3.24 & 1.17 \\
\hline France & Lyon & 45.76 & 4.84 & 37 & 1 & 1578.76 & 4.33 & 1578.74 & 4.33 & 1348.05 & 3.69 & 1.17 \\
\hline France & Rennes & 48.114 & -1.669 & 38 & 0 & 1413.59 & 3.87 & 1413.59 & 3.87 & 1210.02 & 3.32 & 1.17 \\
\hline France & Bordeaux & 44.84 & -0.58 & 37 & 3 & 1608.95 & 4.41 & 1608.44 & 4.41 & 1374.99 & 3.77 & 1.17 \\
\hline Gabon & Libreville & 0.41 & 9.47 & 3 & 48 & 1804.25 & 4.94 & 1802.80 & 4.94 & 1801.52 & 4.94 & 1.00 \\
\hline Gabon & Franceville & -1.62 & 13.60 & 0 & -180 & 1790.85 & 4.91 & 1790.85 & 4.91 & 1790.85 & 4.91 & 1.00 \\
\hline Gambia & Banjul & 13.45 & -16.59 & 16 & 4 & 2288.49 & 6.27 & 2288.15 & 6.27 & 2226.59 & 6.10 & 1.03 \\
\hline Georgia & Tbilisi & 41.70 & 44.82 & 35 & 4 & 1737.14 & 4.76 & 1736.14 & 4.76 & 1509.04 & 4.13 & 1.15 \\
\hline Germany & Berlin & 52.52 & 13.38 & 38 & -4 & 1261.69 & 3.46 & 1261.22 & 3.46 & 1077.30 & 2.95 & 1.17 \\
\hline Germany & Cologne & 50.94 & 6.96 & 38 & -2 & 1257.92 & 3.45 & 1257.79 & 3.45 & 1072.06 & 2.94 & 1.17 \\
\hline Germany & Munich & 48.14 & 11.58 & 38 & 1 & 1372.50 & 3.76 & 1372.46 & 3.76 & 1169.59 & 3.20 & 1.17 \\
\hline Germany & Hamburg & 53.55 & 9.99 & 38 & -1 & 1185.43 & 3.25 & 1185.34 & 3.25 & 1011.99 & 2.77 & 1.17 \\
\hline
\end{tabular}


Table A1. Cont.

\begin{tabular}{|c|c|c|c|c|c|c|c|c|c|c|c|c|}
\hline Ghana & Accra & 5.60 & -0.19 & 9 & 28 & 2131.69 & 5.84 & 2126.79 & 5.83 & 2109.18 & 5.78 & 1.01 \\
\hline Gibraltar & Catalan Bay & 36.14 & -5.34 & 31 & -27 & 1884.42 & 5.16 & 1845.21 & 5.06 & 1654.38 & 4.53 & 1.12 \\
\hline Greece & Athens & 37.98 & 23.73 & 32 & 2 & 2055.37 & 5.63 & 2055.21 & 5.63 & 1818.83 & 4.98 & 1.13 \\
\hline Guatemala & Guatemala City & 14.63 & -90.51 & 18 & -2 & 2007.60 & 5.50 & 2007.56 & 5.50 & 1939.68 & 5.31 & 1.03 \\
\hline Guinea & Kindia & 10.04 & -12.86 & 15 & 9 & 2135.68 & 5.85 & 2134.46 & 5.85 & 2085.93 & 5.71 & 1.02 \\
\hline Guinea & Kankan & 10.38 & -9.31 & 15 & 9 & 2256.01 & 6.18 & 2254.54 & 6.18 & 2202.55 & 6.03 & 1.02 \\
\hline Guinea-Bissau & Bissau & 11.86 & -15.58 & 14 & 5 & 2223.35 & 6.09 & 2222.89 & 6.09 & 2169.36 & 5.94 & 1.02 \\
\hline Guyana & Georgetown & 6.80 & -58.16 & 7 & -14 & 2004.88 & 5.49 & 2004.09 & 5.49 & 1993.37 & 5.46 & 1.01 \\
\hline Haiti & Port-Au-Prince & 18.55 & -72.34 & 21 & -16 & 2244.58 & 6.15 & 2235.80 & 6.13 & 2124.32 & 5.82 & 1.05 \\
\hline Honduras & Tegucigalpa & 14.07 & -87.17 & 16 & 1 & 1956.36 & 5.36 & 1956.34 & 5.36 & 1905.88 & 5.22 & 1.03 \\
\hline Honduras & Catacamas & 14.84 & -85.88 & 14 & -7 & 1886.46 & 5.17 & 1885.78 & 5.17 & 1845.84 & 5.06 & 1.02 \\
\hline Hong Kong & Hong Kong & 22.42 & 114.16 & 20 & 13 & 1523.23 & 4.17 & 1520.24 & 4.17 & 1463.19 & 4.01 & 1.04 \\
\hline Hungary & Budapest & 47.50 & 19.04 & 37 & -5 & 1512.04 & 4.14 & 1510.81 & 4.14 & 1298.57 & 3.56 & 1.16 \\
\hline Hungary & Debrecen & 47.53 & 21.63 & 37 & 0 & 1502.57 & 4.12 & 1502.57 & 4.12 & 1288.64 & 3.53 & 1.17 \\
\hline India & New Delhi & 28.61 & 77.21 & 31 & 3 & 2138.18 & 5.86 & 2137.84 & 5.86 & 1921.33 & 5.26 & 1.11 \\
\hline India & Rajkot & 22.30 & 70.80 & 27 & -1 & 2300.66 & 6.30 & 2300.64 & 6.30 & 2108.29 & 5.78 & 1.09 \\
\hline India & Jodhpur & 26.293 & 73.034 & 30 & 0 & 2324.87 & 6.37 & 2324.87 & 6.37 & 2098.01 & 5.75 & 1.11 \\
\hline India & Chennai & 13.08 & 80.27 & 15 & 3 & 2137.98 & 5.86 & 2137.87 & 5.86 & 2088.66 & 5.72 & 1.02 \\
\hline India & Nagercoil & 8.18 & 77.41 & 9 & 1 & 2166.94 & 5.94 & 2166.92 & 5.94 & 2143.62 & 5.87 & 1.01 \\
\hline Indonesia & Jakarta & -6.17 & 106.83 & 10 & -180 & 1852.98 & 5.08 & 1852.98 & 5.08 & 1835.41 & 5.03 & 1.01 \\
\hline Indonesia & Balikpapan & -1.24 & 116.85 & 4 & 114 & 1685.95 & 4.62 & 1678.05 & 4.60 & 1675.83 & 4.59 & 1.00 \\
\hline Iran & Tehran & 35.69 & 51.42 & 32 & -2 & 2083.70 & 5.71 & 2083.35 & 5.71 & 1850.42 & 5.07 & 1.13 \\
\hline Iran & Tabriz & 38.09 & 46.27 & 32 & -10 & 2025.04 & 5.55 & 2023.06 & 5.54 & 1795.77 & 4.92 & 1.13 \\
\hline Iran & Yazd & 31.90 & 54.36 & 31 & -3 & 2453.82 & 6.72 & 2453.18 & 6.72 & 2183.47 & 5.98 & 1.12 \\
\hline Iraq & Baghdad & 33.32 & 44.37 & 31 & 1 & 2280.20 & 6.25 & 2280.20 & 6.25 & 2038.03 & 5.58 & 1.12 \\
\hline Iraq & Mosul & 36.35 & 43.15 & 32 & 0 & 2178.96 & 5.97 & 2178.96 & 5.97 & 1928.69 & 5.28 & 1.13 \\
\hline Iraq & Basrah & 30.52 & 47.80 & 29 & 0 & 2324.75 & 6.37 & 2324.75 & 6.37 & 2117.19 & 5.80 & 1.10 \\
\hline Ireland & Dublin & 53.35 & -6.27 & 40 & -3 & 1144.43 & 3.14 & 1144.21 & 3.13 & 968.59 & 2.65 & 1.18 \\
\hline Ireland & Kilkenny & 52.65 & -7.25 & 38 & -1 & 1129.48 & 3.09 & 1129.44 & 3.09 & 973.43 & 2.67 & 1.16 \\
\hline
\end{tabular}


Table A1. Cont.

\begin{tabular}{|c|c|c|c|c|c|c|c|c|c|c|c|c|}
\hline Israel & Haifa & 32.79 & 34.99 & 29 & 6 & 2167.67 & 5.94 & 2165.42 & 5.93 & 1958.53 & 5.37 & 1.11 \\
\hline Israel & Eilat & 29.56 & 34.95 & 29 & 3 & 2526.58 & 6.92 & 2525.82 & 6.92 & 2280.23 & 6.25 & 1.11 \\
\hline Italy & Rome & 41.90 & 12.50 & 36 & 2 & 1935.18 & 5.30 & 1935.05 & 5.30 & 1653.95 & 4.53 & 1.17 \\
\hline Italy & Catania & 37.51 & 15.08 & 33 & -4 & 2049.02 & 5.61 & 2047.78 & 5.61 & 1804.48 & 4.94 & 1.13 \\
\hline Ivory Coast & Yamoussoukro & 6.83 & -5.29 & 10 & 36 & 2001.01 & 5.48 & 1991.39 & 5.46 & 1970.58 & 5.40 & 1.01 \\
\hline Jamaica & Kingston & 18.02 & -76.80 & 19 & -24 & 2020.66 & 5.54 & 2007.25 & 5.50 & 1933.03 & 5.30 & 1.04 \\
\hline Jordan & Amman & 31.95 & 35.91 & 28 & 4 & 2313.66 & 6.34 & 2312.82 & 6.34 & 2102.64 & 5.76 & 1.10 \\
\hline Jordan & Zarqa & 32.063 & 36.09 & 28 & 2 & 2315.94 & 6.35 & 2315.57 & 6.34 & 2101.66 & 5.76 & 1.10 \\
\hline Jordan & Irbid & 32.56 & 35.85 & 9 & 7 & 2268.95 & 6.22 & 2266.16 & 6.21 & 2049.04 & 5.61 & 1.11 \\
\hline Kazakhstan & Nur-Sultan & 51.16 & 71.47 & 38 & -5 & 1442.67 & 3.95 & 1442.49 & 3.95 & 1231.44 & 3.37 & 1.17 \\
\hline Kazakhstan & Zhezqazghan & 47.80 & 67.70 & 36 & -3 & 1646.43 & 4.51 & 1645.54 & 4.51 & 1416.89 & 3.88 & 1.16 \\
\hline Kenya & Nairobi & -1.29 & 36.82 & 0 & 0 & 1998.16 & 5.47 & 1998.16 & 5.47 & 1998.16 & 5.47 & 1.00 \\
\hline Kosovo & Prishtina & 42.66 & 21.17 & 30 & 0 & 1613.38 & 4.42 & 1613.38 & 4.42 & 1419.47 & 3.89 & 1.14 \\
\hline Kuwait & Kuwait City & 29.38 & 47.98 & 28 & -1 & 2380.38 & 6.52 & 2380.37 & 6.52 & 2173.16 & 5.95 & 1.10 \\
\hline Kyrgyz Republic & Bishkek & 42.87 & 74.57 & 35 & -1 & 1782.39 & 4.88 & 1782.30 & 4.88 & 1550.76 & 4.25 & 1.15 \\
\hline Kyrgyz Republic & Jalal-Abad & 40.93 & 72.98 & 33.00 & 2 & 1882.07 & 5.16 & 1881.77 & 5.16 & 1656.30 & 4.54 & 1.14 \\
\hline Laos & Vientiane & 17.98 & 102.63 & 23.00 & 11 & 1961.04 & 5.37 & 1956.94 & 5.36 & 1852.99 & 5.08 & 1.06 \\
\hline Latvia & Riga & 56.95 & 24.11 & 40 & -1 & 1170.30 & 3.21 & 1170.29 & 3.21 & 982.95 & 2.69 & 1.19 \\
\hline Latvia & Daugavpils & 55.87 & 26.54 & 38 & 0 & 1154.60 & 3.16 & 1154.60 & 3.16 & 982.60 & 2.69 & 1.18 \\
\hline Lebanon & Beirut & 33.89 & 35.50 & 29 & -1 & 2113.95 & 5.79 & 2113.94 & 5.79 & 1909.46 & 5.23 & 1.11 \\
\hline Lesotho & Maseru & -29.32 & 27.49 & 32 & -178 & 2289.04 & 6.27 & 2288.99 & 6.27 & 2026.68 & 5.55 & 1.13 \\
\hline Liberia & Monrovia & 6.32 & 10.81 & 11 & 25 & 1907.17 & 5.23 & 1903.23 & 5.21 & 1881.63 & 5.16 & 1.01 \\
\hline $\begin{array}{c}\text { Libyan Arab } \\
\text { Jamahiriya }\end{array}$ & Tripoli & 32.89 & 13.18 & 30 & 6 & 2267.00 & 6.21 & 2264.80 & 6.20 & 2036.14 & 5.58 & 1.11 \\
\hline Liechtenstein & Vaduz & 47.14 & 9.52 & 37 & 5 & 1326.21 & 3.63 & 1324.96 & 3.63 & 1138.42 & 3.12 & 1.16 \\
\hline Lithuania & Vilnius & 54.69 & 25.28 & 38 & -1 & 1150.50 & 3.15 & 1150.41 & 3.15 & 985.76 & 2.70 & 1.17 \\
\hline Lithuania & Kaunas & 54.90 & 23.890 & 38 & 0 & 1180.46 & 3.23 & 1180.46 & 3.23 & 1007.24 & 2.76 & 1.17 \\
\hline Luxembourg & Luxembourg & 49.61 & 6.13 & 36 & 0 & 1282.81 & 3.51 & 1282.81 & 3.51 & 1120.82 & 3.07 & 1.14 \\
\hline Macedonia & Skopje & 42.00 & 21.44 & 34 & -2 & 1663.28 & 4.56 & 1663.14 & 4.56 & 1461.89 & 4.01 & 1.14 \\
\hline Macedonia & Bitola & 41.03 & 21.33 & 32 & -6 & 1630.95 & 4.47 & 1629.71 & 4.46 & 1456.76 & 3.99 & 1.12 \\
\hline
\end{tabular}


Table A1. Cont.

\begin{tabular}{|c|c|c|c|c|c|c|c|c|c|c|c|c|}
\hline Malaysia & Kuala Lumpur & 3.14 & 101.69 & 2 & -66 & 1802.55 & 4.94 & 1799.80 & 4.93 & 1799.19 & 4.93 & 1.00 \\
\hline Malaysia & Kangar & 6.44 & 100.20 & 7 & -31 & 1945.97 & 5.33 & 1942.29 & 5.32 & 1932.41 & 5.29 & 1.01 \\
\hline Mali & Bamako & 12.64 & -8.00 & 17 & 2 & 2332.23 & 6.39 & 2332.18 & 6.39 & 2261.85 & 6.20 & 1.03 \\
\hline Malta & Valletta & 35.90 & 14.51 & 31 & 8 & 2098.64 & 5.75 & 2097.52 & 5.75 & 1875.20 & 5.14 & 1.12 \\
\hline Mauritania & Nouakchott & 18.07 & -15.96 & 19 & 6 & 2456.65 & 6.73 & 2456.08 & 6.73 & 2360.03 & 6.47 & 1.04 \\
\hline Mauritius & Port Louis & -20.16 & 57.50 & 20 & -165 & 2079.81 & 5.70 & 2076.19 & 5.69 & 1987.61 & 5.45 & 1.04 \\
\hline Mexico & Mexico City & 19.43 & -99.13 & 22 & -18 & 2211.22 & 6.06 & 2199.60 & 6.03 & 2082.58 & 5.71 & 1.06 \\
\hline Mexico & Merida & 20.97 & -89.59 & 21 & -16 & 2063.70 & 5.65 & 2056.68 & 5.63 & 1960.02 & 5.37 & 1.05 \\
\hline Mexico & Ciudad Juárez & 31.69 & -106.42 & 31 & 0 & 2484.94 & 6.81 & 2484.94 & 6.81 & 2190.48 & 6.00 & 1.13 \\
\hline Moldova Republic & Chisinau & 47.01 & 28.863 & 35 & 0 & 1508.85 & 4.13 & 1508.85 & 4.13 & 1310.20 & 3.59 & 1.15 \\
\hline Monaco & Monte Carlo & 43.74 & 7.43 & 38 & -1 & 1895.71 & 5.19 & 1895.64 & 5.19 & 1579.61 & 4.33 & 1.20 \\
\hline Mongolia & Mandalgovi & 45.76 & 106.27 & 42 & 0 & 1895.97 & 5.19 & 1895.97 & 5.19 & 1534.75 & 4.20 & 1.24 \\
\hline Mongolia & Ulgii & 48.97 & 89.970 & 42 & -6 & 1751.26 & 4.80 & 1749.85 & 4.79 & 1412.41 & 3.87 & 1.24 \\
\hline Montenegro & Podgorica & 42.43 & 19.26 & 36 & 1 & 1854.69 & 5.08 & 1854.66 & 5.08 & 1581.32 & 4.33 & 1.17 \\
\hline Morocco & Rabat & 34.02 & -6.84 & 31 & 7 & 2196.62 & 6.02 & 2192.83 & 6.01 & 1947.56 & 5.34 & 1.13 \\
\hline Morocco & Casablanca & 33.57 & -7.59 & 32 & 6 & 2216.54 & 6.07 & 2213.90 & 6.07 & 1963.28 & 5.38 & 1.13 \\
\hline Mozambique & Maputo & -25.97 & 32.57 & 29 & 168 & 2082.81 & 5.71 & 2074.42 & 5.68 & 1884.70 & 5.16 & 1.10 \\
\hline Mozambique & Lichinga & -13.30 & 35.25 & 17 & -164 & 1996.18 & 5.47 & 1992.87 & 5.46 & 1933.83 & 5.30 & 1.03 \\
\hline Myanmar & Naypyitaw & 19.76 & 96.14 & 26 & 5 & 2180.17 & 5.97 & 2179.51 & 5.97 & 2019.55 & 5.53 & 1.08 \\
\hline Myanmar & 'Yangon & 16.80 & 96.16 & 24 & -2 & 1975.38 & 5.41 & 1975.27 & 5.41 & 1852.94 & 5.08 & 1.07 \\
\hline Namibia & Windhoek & -22.57 & 17.08 & 27 & -173 & 2473.43 & 6.78 & 2471.35 & 6.77 & 2266.39 & 6.21 & 1.09 \\
\hline Nepal & Kathmandu & 27.72 & 85.32 & 32 & -2 & 2083.44 & 5.71 & 2083.18 & 5.71 & 1855.30 & 5.08 & 1.12 \\
\hline Netherlands & Amsterdam & 52.37 & 4.89 & 38 & 4 & 1245.27 & 3.41 & 1244.87 & 3.41 & 1064.77 & 2.92 & 1.17 \\
\hline Netherlands & Maastricht & 50.85 & 5.69 & 38 & 0 & 1265.56 & 3.47 & 1265.56 & 3.47 & 1079.98 & 2.96 & 1.17 \\
\hline Nicaragua & Managua & 12.15 & -86.28 & 16 & -12 & 2202.59 & 6.03 & 2199.97 & 6.03 & 2139.88 & 5.86 & 1.03 \\
\hline Nicaragua & Rivas & 11.44 & -85.83 & 14 & 1 & 2113.39 & 5.79 & 2113.38 & 5.79 & 2066.00 & 5.66 & 1.02 \\
\hline Niger & Niamey & 13.52 & 2.13 & 18 & 6 & 2414.85 & 6.62 & 2413.94 & 6.61 & 2331.02 & 6.39 & 1.04 \\
\hline Nigeria & Abuja & 9.06 & 7.49 & 15 & 12 & 2110.16 & 5.78 & 2107.84 & 5.77 & 2053.46 & 5.63 & 1.03 \\
\hline Nigeria & Lagos & 6.45 & 3.40 & 11 & 30 & 1943.48 & 5.32 & 1937.03 & 5.31 & 1915.62 & 5.25 & 1.01 \\
\hline
\end{tabular}


Table A1. Cont.

\begin{tabular}{|c|c|c|c|c|c|c|c|c|c|c|c|c|}
\hline Norway & Oslo & 59.91 & 10.75 & 43 & 1 & 1130.68 & 3.10 & 1130.57 & 3.10 & 910.76 & 2.50 & 1.24 \\
\hline Norway & Tromsø & 69.65 & 18.96 & 49 & 9 & 906.42 & 2.48 & 905.73 & 2.48 & 713.85 & 1.96 & 1.27 \\
\hline Oman & Muscat & 23.60 & 58.54 & 25 & -1 & 2495.07 & 6.84 & 2494.98 & 6.84 & 2321.49 & 6.36 & 1.07 \\
\hline Oman & Salalah & 17.02 & 54.10 & 21 & 4 & 2383.35 & 6.53 & 2382.76 & 6.53 & 2258.85 & 6.19 & 1.05 \\
\hline Pakistan & Islamabad & 33.69 & 73.06 & 33 & 2 & 2099.78 & 5.75 & 2099.36 & 5.75 & 1847.45 & 5.06 & 1.14 \\
\hline Pakistan & Karachi & 24.86 & 67.01 & 28 & 4 & 2377.52 & 6.51 & 2376.65 & 6.51 & 2168.84 & 5.94 & 1.10 \\
\hline Palestine & Jerusalem & 31.78 & 35.31 & 28 & 2 & 2275.05 & 6.23 & 2274.88 & 6.23 & 2076.64 & 5.69 & 1.10 \\
\hline Palestine & Gaza & 31.53 & 34.46 & 28 & 10 & 2299.91 & 6.30 & 2294.36 & 6.29 & 2079.07 & 5.70 & 1.10 \\
\hline Panama & Panama City & 8.98 & -79.52 & 11 & -35 & 1747.42 & 4.79 & 1739.50 & 4.77 & 1718.60 & 4.71 & 1.01 \\
\hline Paraguay & Asuncion & -25.29 & -57.62 & 23 & -170 & 1890.38 & 5.18 & 1887.57 & 5.17 & 1778.81 & 4.87 & 1.06 \\
\hline Peru & Lima & -12.05 & 77.04 & 10 & 155 & 1761.39 & 4.83 & 1757.43 & 4.81 & 1741.46 & 4.77 & 1.01 \\
\hline Poland & Warsaw & 52.23 & 21.01 & 38 & -3 & 1273.84 & 3.49 & 1273.69 & 3.49 & 1086.43 & 2.98 & 1.17 \\
\hline Poland & Bielsko-Biala & 49.82 & 19.06 & 38 & -2 & 1255.06 & 3.44 & 1254.91 & 3.44 & 1073.01 & 2.94 & 1.17 \\
\hline Poland & Gdynia & 54.52 & 18.55 & 40 & 0 & 1249.85 & 3.42 & 1249.85 & 3.42 & 1051.69 & 2.88 & 1.19 \\
\hline Portugal & Lisbon & 38.72 & -9.14 & 33 & 5 & 1994.31 & 5.46 & 1992.69 & 5.46 & 1751.20 & 4.80 & 1.14 \\
\hline Qatar & Doha & 25.29 & 51.53 & 25 & 0 & 2431.34 & 6.66 & 2431.34 & 6.66 & 2266.09 & 6.21 & 1.07 \\
\hline Romania & Bucharest & 44.43 & 26.10 & 34 & 5 & 1610.98 & 4.41 & 1610.02 & 4.41 & 1406.15 & 3.85 & 1.14 \\
\hline Romania & Craiova & 44.315 & 23.828 & 35 & 4 & 1642.53 & 4.50 & 1641.27 & 4.50 & 1431.19 & 3.92 & 1.15 \\
\hline Romania & Botoșani & 47.74 & 26.67 & 32 & 2 & 1451.10 & 3.98 & 1450.93 & 3.98 & 1252.32 & 3.43 & 1.16 \\
\hline Russia & Saint Petersburg & 59.94 & 30.32 & 41 & 3 & 1076.88 & 2.95 & 1076.41 & 2.95 & 897.41 & 2.46 & 1.20 \\
\hline Russia & Omsk & 54.99 & 73.36 & 40 & -3 & 1326.81 & 3.64 & 1326.34 & 3.63 & 1105.67 & 3.03 & 1.20 \\
\hline Russia & Barnaul & 53.35 & 83.78 & 40 & -1 & 1355.12 & 3.71 & 1355.10 & 3.71 & 1136.97 & 3.11 & 1.19 \\
\hline Russia & Murmansk & 68.97 & 33.09 & 47 & -5 & 866.53 & 2.37 & 865.44 & 2.37 & 684.00 & 1.87 & 1.27 \\
\hline Rwanda & Kigali & -1.94 & 30.06 & 4 & -167 & 1930.06 & 5.29 & 1929.85 & 5.29 & 1926.68 & 5.28 & 1.00 \\
\hline Saint Kitts And Nevis & Basseterre & 17.30 & -62.72 & 19 & -16 & 2136.25 & 5.85 & 2130.80 & 5.84 & 2051.04 & 5.62 & 1.04 \\
\hline Saint Lucia & Castries & 14.01 & -60.99 & 15 & -19 & 2104.18 & 5.76 & 2098.57 & 5.75 & 2046.02 & 5.61 & 1.03 \\
\hline San Marino & San Marino & 43.94 & 12.45 & 34 & 9 & 1592.04 & 4.36 & 1587.17 & 4.35 & 1394.67 & 3.82 & 1.14 \\
\hline Sao Tome \& Principe & Sao Tome & 0.34 & 6.73 & 1 & 0 & 1908.00 & 5.23 & 1908.00 & 5.23 & 1907.91 & 5.23 & 1.00 \\
\hline Saudi Arabia & Riyadh & 24.63 & 46.72 & 25 & 1 & 2493.58 & 6.83 & 2493.48 & 6.83 & 2318.87 & 6.35 & 1.08 \\
\hline
\end{tabular}


Table A1. Cont.

\begin{tabular}{|c|c|c|c|c|c|c|c|c|c|c|c|c|}
\hline Saudi Arabia & Jeddah & 21.58 & 39.17 & 22 & 15 & 2488.38 & 6.82 & 2479.29 & 6.79 & 2344.20 & 6.42 & 1.06 \\
\hline Saudi Arabia & Jazan & 16.89 & 42.57 & 19 & 0 & 2394.38 & 6.56 & 2394.38 & 6.56 & 2300.99 & 6.30 & 1.04 \\
\hline Saudi Arabia & Arar & 30.98 & 41.02 & 29 & 0 & 2456.95 & 6.73 & 2456.95 & 6.73 & 2212.61 & 6.06 & 1.11 \\
\hline Senegal & Dakar & 14.72 & -17.47 & 17 & 2 & 2322.37 & 6.36 & 2322.26 & 6.36 & 2252.59 & 6.17 & 1.03 \\
\hline Serbia & Belgrade & 44.82 & 20.47 & 36 & 0 & 1579.56 & 4.33 & 1579.56 & 4.33 & 1366.20 & 3.74 & 1.16 \\
\hline Seychelles & Victoria & 48.43 & -123.37 & 37 & 5 & 1547.90 & 4.24 & 1546.05 & 4.24 & 1317.54 & 3.61 & 1.17 \\
\hline Sierra Leone & Koidu & 8.62 & -10.96 & 13 & 26 & 2068.93 & 5.67 & 2063.04 & 5.65 & 2027.23 & 5.55 & 1.02 \\
\hline Singapore & Singapore & 1.29 & 103.84 & 0 & 0 & 1733.09 & 4.75 & 1733.09 & 4.75 & 1733.09 & 4.75 & 1.00 \\
\hline Slovakia & Bratislava & 48.15 & 17.11 & 37 & 0 & 1466.30 & 4.02 & 1466.30 & 4.02 & 1256.99 & 3.44 & 1.17 \\
\hline Slovakia & Žilina & 49.22 & 18.74 & 37 & -2 & 1286.53 & 3.52 & 1286.41 & 3.52 & 1108.48 & 3.04 & 1.16 \\
\hline Slovenia & Ljubljana & 46.05 & 14.51 & 34 & 12 & 1428.33 & 3.91 & 1420.87 & 3.89 & 1247.25 & 3.42 & 1.14 \\
\hline Somalia & Mogadishu & 2.05 & 45.32 & 3 & 14 & 2427.88 & 6.65 & 2427.64 & 6.65 & 2423.50 & 6.64 & 1.00 \\
\hline Somalia & Borama & 9.94 & 43.18 & 14 & -24 & 2459.72 & 6.74 & 2450.99 & 6.72 & 2397.80 & 6.57 & 1.02 \\
\hline South Sudan & Juba & 4.85 & 31.59 & 8 & 16 & 2165.23 & 5.93 & 2163.93 & 5.93 & 2147.55 & 5.88 & 1.01 \\
\hline South Sudan & Renk & 11.75 & 32.811 & 18 & 13 & 2325.21 & 6.37 & 2320.93 & 6.36 & 2240.34 & 6.14 & 1.04 \\
\hline South Africa & Johannesburg & -26.20 & 28.05 & 30 & 180 & 2256.50 & 6.18 & 2256.50 & 6.18 & 2020.48 & 5.54 & 1.12 \\
\hline South Africa & Durban & -29.855 & 30.985 & 33 & 178 & 1923.65 & 5.27 & 1922.63 & 5.27 & 1694.33 & 4.64 & 1.13 \\
\hline South Africa & Cape Town & -33.93 & 18.42 & 30 & 173 & 2160.45 & 5.92 & 2157.75 & 5.91 & 1944.01 & 5.33 & 1.11 \\
\hline Spain & Madrid & 40.42 & -3.70 & 36 & 3 & 2099.17 & 5.75 & 2098.86 & 5.75 & 1788.13 & 4.90 & 1.17 \\
\hline Spain & Barcelona & 41.39 & 2.17 & 37 & 2 & 1972.30 & 5.40 & 1971.63 & 5.40 & 1662.81 & 4.56 & 1.19 \\
\hline Spain & Málaga & 36.72 & -4.43 & 34 & 5 & 2142.65 & 5.87 & 2141.03 & 5.87 & 1869.34 & 5.12 & 1.15 \\
\hline Sri-Lanka & Colombo & 6.93 & 79.86 & 8 & -9 & 2109.74 & 5.78 & 2109.31 & 5.78 & 2094.87 & 5.74 & 1.01 \\
\hline Sri-Lanka & Jaffna & 9.66 & 80.03 & 8 & -8 & 2153.39 & 5.90 & 2153.05 & 5.90 & 2138.77 & 5.86 & 1.01 \\
\hline $\begin{array}{c}\text { St. } \\
\text { Vincent/Grenadines }\end{array}$ & Kingstown & 13.16 & -61.23 & 14 & -17 & 2083.32 & 5.71 & 2079.13 & 5.70 & 2035.39 & 5.58 & 1.02 \\
\hline Sudan & Khartoum & 15.59 & 32.54 & 19 & 4 & 2543.61 & 6.97 & 2542.19 & 6.96 & 2435.33 & 6.67 & 1.04 \\
\hline Sudan & El Obeid & 13.18 & 30.22 & 18 & 6 & 2458.61 & 6.74 & 2457.59 & 6.73 & 2367.66 & 6.49 & 1.04 \\
\hline Suriname & Paramaribo & 5.85 & -55.20 & 6 & -53 & 1946.84 & 5.33 & 1937.57 & 5.31 & 1930.37 & 5.29 & 1.00 \\
\hline Swaziland & Mbabane & -26.31 & 31.14 & 31 & 177 & 1928.83 & 5.28 & 1927.79 & 5.28 & 1724.97 & 4.73 & 1.12 \\
\hline
\end{tabular}


Table A1. Cont.

\begin{tabular}{|c|c|c|c|c|c|c|c|c|c|c|c|c|}
\hline Sweden & Stockholm & 59.33 & 18.07 & 43 & 1 & 1172.53 & 3.21 & 1172.50 & 3.21 & 961.01 & 2.63 & 1.22 \\
\hline Sweden & Luleå & 65.58 & 22.16 & 48 & -3 & 1188.99 & 3.26 & 1188.74 & 3.26 & 908.70 & 2.49 & 1.31 \\
\hline Switzerland & Bern & 46.95 & 7.45 & 41 & 2 & 1592.63 & 4.36 & 1592.59 & 4.36 & 1291.08 & 3.54 & 1.23 \\
\hline Syrian Arab Republic & Damascus & 33.51 & 36.28 & 31 & -8 & 2335.49 & 6.40 & 2334.01 & 6.39 & 2073.87 & 5.68 & 1.13 \\
\hline Syrian Arab Republic & Homs & 34.73 & 36.716 & 30 & 7 & 2190.91 & 6.00 & 2187.95 & 5.99 & 1964.10 & 5.38 & 1.11 \\
\hline Syrian Arab Republic & Aleppo & 36.20 & 37.13 & 33 & -6 & 2160.63 & 5.92 & 2160.10 & 5.92 & 1894.68 & 5.19 & 1.14 \\
\hline Tajikistan & Dushanbe & 38.56 & 68.79 & 31 & -4 & 1867.17 & 5.12 & 1866.30 & 5.11 & 1665.90 & 4.56 & 1.12 \\
\hline Tanzania & Dodoma & -6.16 & 35.75 & 8 & 160 & 2365.45 & 6.48 & 2362.99 & 6.47 & 2346.13 & 6.43 & 1.01 \\
\hline Tanzania & Songea & -10.65 & 35.64 & 12 & 168 & 2025.61 & 5.55 & 2024.03 & 5.55 & 1994.46 & 5.46 & 1.01 \\
\hline Thailand & Bangkok & 13.76 & 100.50 & 17 & 0 & 1994.13 & 5.46 & 1994.13 & 5.46 & 1935.70 & 5.30 & 1.03 \\
\hline Thailand & $\begin{array}{l}\text { Mueang Chiang } \\
\text { Rai }\end{array}$ & 19.91 & 99.84 & 25 & 9 & 2009.07 & 5.50 & 2006.42 & 5.50 & 1880.23 & 5.15 & 1.07 \\
\hline Togo & Lome & 6.13 & 1.23 & 9 & 20 & 2135.78 & 5.85 & 2133.33 & 5.84 & 2112.99 & 5.79 & 1.01 \\
\hline Togo & Dapaong & 10.87 & 0.20 & 16 & 5 & 2271.33 & 6.22 & 2270.77 & 6.22 & 2207.94 & 6.05 & 1.03 \\
\hline Trinidad and Tobago & Port of Spain & 10.66 & -61.51 & 11 & -37 & 1973.87 & 5.41 & 1961.97 & 5.38 & 1938.35 & 5.31 & 1.01 \\
\hline Tunisia & Tunis & 36.81 & 10.18 & 32 & 2 & 2055.49 & 5.63 & 2054.98 & 5.63 & 1824.57 & 5.00 & 1.13 \\
\hline Turkey & Ankara & 39.93 & 32.86 & 32 & -4 & 1856.34 & 5.09 & 1855.51 & 5.08 & 1642.72 & 4.50 & 1.13 \\
\hline Turkey & İstanbul & 41.01 & 28.97 & 32 & 11 & 1746.38 & 4.78 & 1741.66 & 4.77 & 1551.90 & 4.25 & 1.12 \\
\hline Turkey & Hakkâri & 37.58 & 43.74 & 29 & -5 & 1896.31 & 5.20 & 1895.59 & 5.19 & 1722.17 & 4.72 & 1.10 \\
\hline Turkmenistan & Ashgabat & 37.94 & 58.39 & 32 & 0 & 1975.89 & 5.41 & 1975.89 & 5.41 & 1752.51 & 4.80 & 1.13 \\
\hline Uganda & Kampala & 0.35 & 32.58 & 1 & 74 & 1955.52 & 5.36 & 1953.95 & 5.35 & 1953.69 & 5.35 & 1.00 \\
\hline Ukraine & Kyiv & 50.45 & 30.52 & 36 & 1 & 1357.97 & 3.72 & 1357.93 & 3.72 & 1173.62 & 3.22 & 1.16 \\
\hline Ukraine & Lviv & 49.848 & 24.033 & 37 & 1 & 1304.11 & 3.57 & 1304.03 & 3.57 & 1123.40 & 3.08 & 1.16 \\
\hline Ukraine & Odessa & 46.48 & 30.72 & 35 & 4 & 1574.72 & 4.31 & 1574.14 & 4.31 & 1366.41 & 3.74 & 1.15 \\
\hline United States & Washington, D.C & 38.91 & -77.04 & 35 & 1 & 1763.08 & 4.83 & 1762.92 & 4.83 & 1525.77 & 4.18 & 1.16 \\
\hline United States & Minot, ND & 48.23 & -101.29 & 42 & 5 & 1674.01 & 4.59 & 1673.38 & 4.58 & 1359.81 & 3.73 & 1.23 \\
\hline United States & San Antonio, TX & 29.42 & -98.49 & 28 & 7 & 2023.09 & 5.54 & 2020.54 & 5.54 & 1851.56 & 5.07 & 1.09 \\
\hline United States & Los Angeles, CA & 34.05 & -118.24 & 32 & 12 & 2247.35 & 6.16 & 2238.74 & 6.13 & 1966.44 & 5.39 & 1.14 \\
\hline $\begin{array}{l}\text { United Arab } \\
\text { Emirates }\end{array}$ & Abu Dhabi & 24.43 & 54.65 & 25 & 1 & 2481.46 & 6.80 & 2481.38 & 6.80 & 2309.42 & 6.33 & 1.07 \\
\hline
\end{tabular}


Table A1. Cont.

\begin{tabular}{|c|c|c|c|c|c|c|c|c|c|c|c|c|}
\hline $\begin{array}{l}\text { United Arab } \\
\text { Emirates }\end{array}$ & Dubai & 25.27 & 55.30 & 25 & 1 & 2457.38 & 6.73 & 2457.36 & 6.73 & 2277.89 & 6.24 & 1.08 \\
\hline United Kingdom & London & 51.507 & -0.128 & 39 & -3 & 1227.62 & 3.36 & 1227.42 & 3.36 & 1046.30 & 2.87 & 1.17 \\
\hline United Kingdom & York & 53.96 & -1.087 & 40 & -1 & 1142.40 & 3.13 & 1142.34 & 3.13 & 967.71 & 2.65 & 1.18 \\
\hline United Kingdom & Truro & 50.26 & -5.05 & 37 & 6 & 1269.16 & 3.48 & 1268.19 & 3.47 & 1097.53 & 3.01 & 1.16 \\
\hline Uruguay & Montevideo & -34.91 & -56.19 & 30 & -177 & 1802.71 & 4.94 & 1801.84 & 4.94 & 1622.85 & 4.45 & 1.11 \\
\hline Uruguay & Tacuarembo & -31.711 & -55.964 & 29 & -176 & 1814.57 & 4.97 & 1814.47 & 4.97 & 1664.21 & 4.56 & 1.09 \\
\hline Uzbekistan & Tashkent & 41.30 & 69.24 & 33 & 0 & 1924.70 & 5.27 & 1924.70 & 5.27 & 1692.18 & 4.64 & 1.14 \\
\hline Vatican City & Vatican City & 41.90 & 12.45 & 36 & 2 & 1935.25 & 5.30 & 1935.14 & 5.30 & 1653.96 & 4.53 & 1.17 \\
\hline Venezuela & Caracas & 10.48 & -66.90 & 11 & -17 & 1952.14 & 5.35 & 1949.93 & 5.34 & 1927.48 & 5.28 & 1.01 \\
\hline Venezuela & Amazonas & 2.81 & -65.10 & 4 & 0 & 1998.58 & 5.48 & 1998.58 & 5.48 & 1995.50 & 5.47 & 1.00 \\
\hline Vietnam & Hanoi & 21.03 & 105.83 & 16 & 28 & 1483.03 & 4.06 & 1475.95 & 4.04 & 1446.40 & 3.96 & 1.02 \\
\hline Vietnam & Cà Mau & 9.18 & 105.15 & 11 & -25 & 1849.86 & 5.07 & 1845.96 & 5.06 & 1826.08 & 5.00 & 1.01 \\
\hline Yemen & Sana'A & 15.37 & 44.19 & 19 & -23 & 2384.73 & 6.53 & 2370.25 & 6.49 & 2275.92 & 6.24 & 1.04 \\
\hline Yemen & Aden & 12.79 & 45.02 & 15 & 5 & 2430.15 & 6.66 & 2429.76 & 6.66 & 2365.05 & 6.48 & 1.03 \\
\hline Zambia & Lusaka & -15.42 & 28.29 & 22 & -176 & 2252.38 & 6.17 & 2252.05 & 6.17 & 2137.47 & 5.86 & 1.05 \\
\hline Zimbabwe & Harare & -17.83 & 31.03 & 24 & -174 & 2270.50 & 6.22 & 2269.35 & 6.22 & 2131.28 & 5.84 & 1.06 \\
\hline
\end{tabular}


Table A2. In-sample and out-of-sample proposed model performance.

\begin{tabular}{|c|c|c|c|c|c|c|c|c|c|c|c|c|c|}
\hline \multicolumn{4}{|c|}{ Location Coordinates } & \multicolumn{5}{|c|}{ Calculated Model Using PVGIS } & \multicolumn{5}{|c|}{ Proposed Model Using Neural Network } \\
\hline Country & City & $\begin{array}{l}\text { Latitude } \\
\text { (deg.) }\end{array}$ & $\begin{array}{l}\text { Longitude } \\
\text { (deg.) }\end{array}$ & $\begin{array}{c}\text { Optimum } \\
\text { Tilt Angle } \\
\text { (deg.) }\end{array}$ & $\begin{array}{c}\text { Azimuth } \\
\text { Angle } \\
\text { (deg.) }\end{array}$ & $\underset{\left(\mathrm{kWh} / \mathrm{m}^{2}\right)}{\mathrm{AR} 1}$ & $\underset{\left(\mathrm{kWh} / \mathrm{m}^{2}\right)}{\mathrm{AR2}}$ & $\begin{array}{c}\mathrm{AR3} 3 \\
\left(\mathrm{kWh} / \mathrm{m}^{2}\right)\end{array}$ & $\begin{array}{c}\text { Optimum } \\
\text { Tilt Angle } \\
\text { (deg.) }\end{array}$ & $\begin{array}{c}\text { Azimuth } \\
\text { Angle } \\
\text { (deg.) }\end{array}$ & $\underset{\left(\mathrm{kWh} / \mathrm{m}^{2}\right)}{\mathrm{AR} 1}$ & $\begin{array}{c}\text { AR2 } \\
\left(\mathrm{kWh} / \mathrm{m}^{2}\right)\end{array}$ & $\begin{array}{c}\text { AR3 } \\
\left(\mathrm{kWh} / \mathrm{m}^{2}\right)\end{array}$ \\
\hline \multicolumn{14}{|c|}{ In-Sample Testing Set } \\
\hline Sweden & Luleå & 65.58 & 22.16 & 48 & -3 & 1188.99 & 1188.74 & 908.7 & 48.03 & -3.138 & 1219 & 1219 & 925.5 \\
\hline Australia & Geraldton & -28.78 & 114.61 & 28 & -180 & 2301.1 & 2301.1 & 2092.13 & 28 & -180 & 2301 & 2301 & 2092 \\
\hline Norway & Tromsø & 69.65 & 18.96 & 49 & 9 & 906.42 & 905.73 & 713.85 & 48.82 & 10.86 & 848.8 & 860.8 & 703.4 \\
\hline Rwanda & Kigali & -1.94 & 30.06 & 4 & -167 & 1930.06 & 1929.85 & 1926.68 & 4.059 & -167.3 & 1940 & 1933 & 1916 \\
\hline Brazil & $\begin{array}{l}\text { Rio De } \\
\text { Janeiro }\end{array}$ & -22.91 & -43.17 & 24 & -180 & 1872.95 & 1872.95 & 1755.27 & 24 & -180 & 1873 & 1873 & 1755 \\
\hline Burundi & Bujumbura & -3.36 & 29.36 & 8 & -180 & 1982.06 & 1982.06 & 1970.43 & 7.978 & -179.9 & 1974 & 1973 & 1964 \\
\hline Iraq & Mosul & 36.35 & 43.15 & 32 & 0 & 2178.96 & 2178.96 & 1928.69 & 32 & -0.1384 & 2188 & 2188 & 1936 \\
\hline Spain & Málaga & 36.72 & -4.43 & 34 & 5 & 2142.65 & 2141.03 & 1869.34 & 34 & 4.687 & 2156 & 2157 & 1870 \\
\hline Chile & Arica & -18.48 & -70.31 & 18 & -180 & 2274.32 & 2274.32 & 2193.16 & 18.08 & -180 & 2237 & 2241 & 2161 \\
\hline Finland & Helsinki & 60.17 & 24.94 & 42 & 3 & 1125.27 & 1124.86 & 925.59 & 41.92 & 3.342 & 1140 & 1141 & 927.7 \\
\hline Somalia & Mogadishu & 2.05 & 45.32 & 3 & 14 & 2427.88 & 2427.64 & 2423.5 & 2.827 & 14.29 & 2405 & 2382 & 2381 \\
\hline Malaysia & $\begin{array}{c}\text { Kuala } \\
\text { Lumpur }\end{array}$ & 3.14 & 101.69 & 2 & -66 & 1802.55 & 1799.8 & 1799.19 & 1.942 & -65.99 & 1783 & 1785 & 1773 \\
\hline Suriname & Paramaribo & 5.85 & -55.20 & 6 & -53 & 1946.84 & 1937.57 & 1930.37 & 6.055 & -53.1 & 1907 & 1894 & 1894 \\
\hline Benin & Port Novo & 6.50 & 2.63 & 11 & 27 & 1932.3 & 1927.88 & 1906.39 & 11.05 & 27.2 & 1923 & 1918 & 1897 \\
\hline India & Nagercoil & 8.18 & 77.41 & 9 & 1 & 2166.94 & 2166.92 & 2143.62 & 8.986 & 1.572 & 2123 & 2133 & 2108 \\
\hline Sri-Lanka & Jaffna & 9.66 & 80.03 & 8 & -8 & 2153.39 & 2153.05 & 2138.77 & 8.038 & -8.211 & 2173 & 2165 & 2157 \\
\hline China & Guigang & 23.11 & 109.60 & 19 & 17 & 1400.07 & 1396.45 & 1354.5 & 18.99 & 17.11 & 1392 & 1389 & 1347 \\
\hline Lebanon & Beirut & 33.89 & 35.50 & 29 & -1 & 2113.95 & 2113.94 & 1909.46 & 29.07 & -1.031 & 2118 & 2118 & 1912 \\
\hline Malta & Valletta & 35.90 & 14.51 & 31 & 8 & 2098.64 & 2097.52 & 1875.2 & 31.03 & 7.936 & 2105 & 2104 & 1883 \\
\hline
\end{tabular}


Table A2. Cont.

\begin{tabular}{|c|c|c|c|c|c|c|c|c|c|c|c|c|c|}
\hline United States & $\begin{array}{l}\text { Washington, } \\
\text { D.C }\end{array}$ & 38.91 & -77.04 & 35 & 1 & 1763.08 & 1762.92 & 1525.77 & 34.85 & 0.6785 & 1712 & 1689 & 1552 \\
\hline Italy & Rome & 41.90 & 12.50 & 36 & 2 & 1935.18 & 1935.05 & 1653.95 & 36.13 & 2.23 & 1925 & 1924 & 1645 \\
\hline Croatia & Zadar & 44.12 & 15.23 & 37 & 2 & 1801.18 & 1801.08 & 1530.99 & 36.99 & 2.03 & 1799 & 1799 & 1530 \\
\hline Canada & Ottawa & 45.42 & -75.70 & 37 & 0 & 1563.56 & 1563.56 & 1325.33 & 36.95 & 0.0682 & 1563 & 1560 & 1341 \\
\hline Liechtenstein & Vaduz & 47.14 & 9.52 & 37 & 5 & 1326.21 & 1324.96 & 1138.42 & 37 & 4.99 & 1326 & 1325 & 1139 \\
\hline Germany & Munich & 48.14 & 11.58 & 38 & 1 & 1372.5 & 1372.46 & 1169.59 & 37.99 & 1.023 & 1373 & 1373 & 1170 \\
\hline Belize & Belmopan & 17.25 & -88.76 & 17 & 7 & 1907.61 & 1906.68 & 1850.78 & 17 & 7.008 & 1907 & 1906 & 1850 \\
\hline Bhutan & Thimphu & 27.47 & 89.63 & 31 & -15 & 1913.66 & 1902.28 & 1704.45 & 31.06 & -15.16 & 1926 & 1913 & 1711 \\
\hline Australia & Karratha & -20.73 & 116.84 & 23 & -180 & 2490.05 & 2490.05 & 2343.49 & 22.99 & -180.9 & 2520 & 2494 & 2339 \\
\hline South Africa & Johannesburg & -26.20 & 28.05 & 30 & 180 & 2256.5 & 2256.5 & 2020.48 & 29.94 & 179.8 & 2262 & 2265 & 2026 \\
\hline Namibia & Windhoek & -22.57 & 17.08 & 27 & -173 & 2473.43 & 2471.35 & 2266.39 & 26.99 & -173.1 & 2466 & 2468 & 2256 \\
\hline \multicolumn{14}{|c|}{ Out-of-Sample Testing Set } \\
\hline Egypt & Port Said & 31.263 & 32.308 & 29 & 3 & 2316.73 & 2314.47 & 2093.57 & 28.98 & 3 & 2315 & 2313 & 2093 \\
\hline Jordan & Zarqa & 32.063 & 36.09 & 28 & 2 & 2315.94 & 2315.57 & 2101.66 & 27.32 & 2.042 & 2474 & 2477 & 2226 \\
\hline $\begin{array}{c}\text { Syrian Arab } \\
\text { Republic }\end{array}$ & Homs & 34.73 & 36.716 & 30 & 7 & 2190.91 & 2187.95 & 1964.1 & 30 & 6.999 & 2191 & 2188 & 1964 \\
\hline Romania & Craiova & 44.315 & 23.828 & 35 & 4 & 1642.53 & 1641.27 & 1431.19 & 35 & 4.001 & 1643 & 1641 & 1431 \\
\hline Ukraine & Lviv & 49.848 & 24.033 & 37 & 1 & 1304.11 & 1304.03 & 1123.4 & 37 & 1 & 1304 & 1304 & 1123 \\
\hline South Africa & Durban & -29.855 & 30.985 & 33 & 178 & 1923.65 & 1922.63 & 1694.33 & 33 & 178 & 1924 & 1923 & 1694 \\
\hline France & Rennes & 48.114 & -1.669 & 38 & 0 & 1413.59 & 1413.59 & 1210.02 & 38 & 0.00012 & 1414 & 1414 & 1210 \\
\hline Colombia & Medellin & 6.254 & -75.576 & 5 & -8 & 1896.07 & 1895.95 & 1890.18 & 5 & -8 & 1896 & 1896 & 1890 \\
\hline India & Jodhpur & 26.293 & 73.034 & 30 & 0 & 2324.87 & 2324.87 & 2098.01 & 30 & 0.0005 & 2325 & 2325 & 2098 \\
\hline Uruguay & Tacuarembo & -31.711 & -55.964 & 29 & -176 & 1814.57 & 1814.47 & 1664.21 & 29 & -176 & 1815 & 1814 & 1664 \\
\hline
\end{tabular}

AR1: annual irradiation $\left(\mathrm{kWh} / \mathrm{m}^{2}\right)$ at optimum tilt angle and orientation. AR2: annual irradiation $\left(\mathrm{kWh} / \mathrm{m}^{2}\right)$ at optimum tilt angle (azimuth angle $=0$ for Northern Hemisphere and 180 for Southern). AR3: annual irradiation $\left(\mathrm{kWh} / \mathrm{m}^{2}\right)$ at horizontal surface. DR1: daily average irradiation $\left(\mathrm{kWh} / \mathrm{m}^{2} /\right.$ day) at optimum tilt angle and orientation. DR2: daily average irradiation $\left(\mathrm{kWh} / \mathrm{m}^{2} /\right.$ day) at optimum tilt angle (azimuth angle $=0$ for Northern Hemisphere and 180 for Southern). DR3: daily average irradiation $\left(\mathrm{kWh} / \mathrm{m}^{2} /\right.$ day) at horizontal surface. 


\section{References}

1. Hernandez-Escobedo, Q.; Rodriguez-Garcia, E.; Saldaña-Flores, R.; Fernández-García, A.; Manzano-Agugliaro, F. Solar energy resource assessment in Mexican states along the Gulf of Mexico. Renew. Sustain. Energy Rev. 2015, 43, 216-238. [CrossRef]

2. Hailu, G.; Fung, A.S. Optimum tilt angle and orientation of photovoltaic thermal system for application in greater Toronto area, Canada. Sustainability 2019, 11, 6443. [CrossRef]

3. REN21. Renewables 2020 Global Status Report. Paris: REN21 Secretariat. 2020. Available online: https: //www.ren21.net/wp-content/uploads/2019/05/gsr_2020_full_report_en.pdf (accessed on 1 December 2020).

4. United Nations General Assembly. Transforming our World: The 2030 Agenda for Sustainable Development; Division for Sustainable Development Goals: New York, NY, USA, 2015; pp. 1-35.

5. Dholakia, H.H. Solar powered healthcare in developing countries. Nat. Energy 2018, 3, 705-707. [CrossRef]

6. Green, M.A.; Dunlop, E.D.; Levi, D.H.; Hohl-Ebinger, J.; Yoshita, M.; Ho-Baillie, A.W. Solar cell efficiency tables (version 56). Prog. Photovolt. Res. Appl. 2020, 28, 629-638. [CrossRef]

7. Salameh, T.; Tawalbeh, M.; Juaidi, A.; Abdallah, R.; Issa, S.; Alami, A.H. A novel numerical simulation model for the PVT water system in the GCC region. In Proceedings of the 2020 Advances in Science and Engineering Technology International Conferences (ASET), Rome, Italy, 10-11 December 2020; pp. 1-5.

8. Abdallah, R.; Juaidi, A.; Assad, M.; Salameh, T.; Manzano-Agugliaro, F. Energy Recovery from Waste Tires Using Pyrolysis: Palestine as Case of Study. Energies 2020, 13, 1817. [CrossRef]

9. Salameh, T.; Tawalbeh, M.; Juaidi, A.; Abdallah, R.; Hamid, A.-K. A novel three-dimensional numerical model for PV/T water system in hot climate region. Renew. Energy 2020, 164, 1320-1333. [CrossRef]

10. Hafez, A.; Soliman, A.; El-Metwally, K.; Ismail, I. Tilt and azimuth angles in solar energy applications-A review. Renew. Sustain. Energy Rev. 2017, 77, 147-168. [CrossRef]

11. Despotovic, M.; Nedic, V. Comparison of optimum tilt angles of solar collectors determined at yearly, seasonal and monthly levels. Energy Convers. Manag. 2015, 97, 121-131. [CrossRef]

12. Juaidi, A.; Montoya, F.G.; Ibrik, I.H.; Manzano-Agugliaro, F. An overview of renewable energy potential in Palestine. Renew. Sustain. Energy Rev. 2016, 65, 943-960. [CrossRef]

13. Juaidi, A.; Montoya, F.G.; Gázquez, J.A.; Manzano-Agugliaro, F. An overview of energy balance compared to sustainable energy in United Arab Emirates. Renew. Sustain. Energy Rev. 2016, 55, 1195-1209. [CrossRef]

14. Chen, X.M.; Li, Y.; Zhao, B.Y.; Wang, R.Z. Are the optimum angles of photovoltaic systems so important? Renew. Sustain. Energy Rev. 2020, 124, 109791. [CrossRef]

15. Castellano, N.N.; Parra, J.A.G.; Valls-Guirado,J.; Manzano-Agugliaro, F. Optimal displacement of photovoltaic array's rows using a novel shading model. Appl. Energy 2015, 144, 1-9. [CrossRef]

16. Takilalte, A.; Harrouni, S.; Yaiche, M.R.; Mora-López, L. New approach to estimate 5-min global solar irradiation data on tilted planes from horizontal measurement. Renew. Energy 2020, 145, 2477-2488. [CrossRef]

17. Novas, N.; Fernández-García, A.; Manzano-Agugliaro, F. A Simplified Method to Avoid Shadows at Parabolic-Trough Solar Collectors Facilities. Symmetry 2020, 12, 278. [CrossRef]

18. Racharla, S.; Rajan, K. Solar tracking system-A review. Int. J. Sustain. Eng. 2017, 10, 72-81.

19. Mousazadeh, H.; Keyhani, A.; Javadi, A.; Mobli, H.; Abrinia, K.; Sharifi, A. A review of principle and sun-tracking methods for maximizing solar systems output. Renew. Sustain. Energy Rev. 2009, 13, 1800-1818. [CrossRef]

20. Abdallah, R.; Juaidi, A.; Abdel-Fattah, S.; Manzano-Agugliaro, F. Estimating the Optimum Tilt Angles for South-Facing Surfaces in Palestine. Energies 2020, 13, 623. [CrossRef]

21. Smith, C.J.; Forster, P.M.; Crook, R. An all-sky radiative transfer method to predict optimal tilt and azimuth angle of a solar collector. Sol. Energy 2016, 123, 88-101. [CrossRef]

22. Le Roux, W.G. Optimum tilt and azimuth angles for fixed solar collectors in South Africa using measured data. Renew. Energy 2016, 96, 603-612. [CrossRef]

23. Fouad, M.; Shihata, L.A.; Morgan, E.I. An integrated review of factors influencing the performance of photovoltaic panels. Renew. Sustain. Energy Rev. 2017, 80, 1499-1511. [CrossRef]

24. Photovoltaic Geographical Information System. European Commission. PVGIS (2019). Available online: https://re.jrc.ec.europa.eu/pvg_tools/en/tools.html (accessed on 1 December 2020). 
25. Mira, J. Symbols versus connections: 50 years of artificial intelligence. Neurocomputing 2008, 71, 671-680. [CrossRef]

26. Jyothi, J.; Veena, M.B. An Efficient and Smart Control of Solar Panel Orientation using Machine Learning. In Proceedings of the 2019 Global Conference for Advancement in Technology (GCAT), Bangalore, India, 18-20 October 2019; pp. 1-5.

27. Kim, G.Y.; Han, D.S.; Lee, Z. Solar Panel Tilt Angle Optimization Using Machine Learning Model: A Case Study of Daegu City, South Korea. Energies 2020, 13, 529. [CrossRef]

28. El-Kassaby, M. Monthly and daily optimum tilt angle for south facing solar collectors; theoretical model, experimental and empirical correlations. Sol. Wind. Technol. 1988, 5, 589-596. [CrossRef]

29. Morcos, V. Optimum tilt angle and orientation for solar collectors in Assiut, Egypt. Renew. Energy 1994, 4, 291-298. [CrossRef]

30. Hartley, L.E.; Lozano, J.A.M.; Utrillas, M.; Tena, F.; Pedrós, R. The optimisation of the angle of inclination of a solar collector to maximise the incident solar radiation. Renew. Energy 1999, 17, 291-309. [CrossRef]

31. Yakup, M.A.B.H.M.; Malik, A. Optimum tilt angle and orientation for solar collector in Brunei Darussalam. Renew. Energy 2001, 24, 223-234. [CrossRef]

32. Tang, R.; Wu, T. Optimal tilt-angles for solar collectors used in China. Appl. Energy 2004, 79, $239-248$. [CrossRef]

33. Ulgen, K. Optimum tilt angle for solar collectors. Energy Sources Part A Recovery Util. Environ. Eff. 2006, 28, 1171-1180. [CrossRef]

34. Skeiker, K. Optimum tilt angle and orientation for solar collectors in Syria. Energy Convers. Manag. 2009, 50, 2439-2448. [CrossRef]

35. Talebizadeh, P.; Mehrabian, M.A.; Abdolzadeh, M. Determination of Optimum Slope Angles of Solar Collectors Based on New Correlations. Energy Sources Part A Recovery Util. Environ. Eff. 2011, 33, 1567-1580. [CrossRef]

36. Darhmaoui, H.; Lahjouji, D. Latitude Based Model for Tilt Angle Optimization for Solar Collectors in the Mediterranean Region. Energy Procedia 2013, 42, 426-435. [CrossRef]

37. Khasawneh, Q.A.; Damra, Q.A.; Salman, B.; Husni, O. Determining the Optimum Tilt Angle for Solar Applications in Northern Jordan. Jordan J. Mech. Ind. Eng. 2015, 9, 187-193.

38. Hartner, M.; Ortner, A.; Hiesl, A.; Haas, R. East to west-The optimal tilt angle and orientation of photovoltaic panels from an electricity system perspective. Appl. Energy 2015, 160, 94-107. [CrossRef]

39. Safdarian, F.; Nazari, M.E. Optimal tilt angle and orientation for solar collectors in Iran. In Proceedings of the 2015 IEEE 10th International Symposium on Diagnostics for Electrical Machines, Power Electronics and Drives (SDEMPED), Guarda, Portugal, 1-4 September 2015; pp. 494-500.

40. Berisha, X.; Zeqiri, A.; Meha, D. Solar Radiation-The Estimation of the Optimum Tilt Angles for South-Facing Surfaces in Pristina. 2017. Available online: https://www.google.com.hk/url?sa=t\&rct=j\& $\mathrm{q}=\&$ esrc=s\&source=web\&cd=\&ved=2ahUKEwjZoeyVo7PtAhUOA4gKHWNoBC0QFjAEegQIAhAC\& url=https $\% 3 \mathrm{~A} \% 2 \mathrm{~F} \% 2 \mathrm{Fwww}$.preprints.org $\% 2$ Fmanuscript $\% 2 \mathrm{~F} 201708.0010 \% 2 \mathrm{Fv} 1 \% 2 \mathrm{Fdownload \& usg=}$ AOvVaw3wBnBGjwMOe3yc41wJimo6 (accessed on 1 December 2020).

41. Guo, M.; Zang, H.; Gao, S.; Chen, T.; Xiao, J.; Cheng, L.; Wei, Z.; Sun, G. Optimal Tilt Angle and Orientation of Photovoltaic Modules Using HS Algorithm in Different Climates of China. Appl. Sci. 2017, 7, 1028. [CrossRef]

42. Jacobson, M.Z.; Jadhav, V. World estimates of PV optimal tilt angles and ratios of sunlight incident upon tilted and tracked PV panels relative to horizontal panels. Sol. Energy 2018, 169, 55-66. [CrossRef]

43. Abdulsalam, H.S.; Alibaba, H.Z. Optimum Tilt Angle for Photovoltaic Panels in Famagusta, Cyprus. IJSSHR 2019, 7, 29-35.

44. Sahu, S.K.; Tripathi, N.; Tripathi, S. A model driven optimization approach to determine tilt angle of solar collector in India. Int. J. Adv. Res. Eng. Technol. 2019, 10, 2019. [CrossRef]

45. Adu, T.F.; Anto, E.K.; Ramde, E.; Mensah, L.D. Determination of Optimum Tilt Angle for Rooftop Solar Photovoltaic System Installation for KikuKinderhaus in Kumasi. Int. J. Energy Environ. Sci. 2020, 5, 7. [CrossRef]

46. Kallioğlu, M.A.; Durmuş, A.; Karakaya, H.; Yılmaz, A. Empirical calculation of the optimal tilt angle for solar collectors in northern hemisphere. Energy Sources Part A Recovery Util. Environ. Eff. 2020, 42, 1335-1358. [CrossRef] 
47. Pourfayaz, F.; Shirmohammadi, R.; Maleki, A.; Kasaeian, A. Improvement of solar flat-plate collector performance by optimum tilt angle and minimizing top heat loss coefficient using particle swarm optimization. Energy Sci. Eng. 2020, 8, 2771-2783. [CrossRef]

48. Sugirianta, I.B.K.; Sunaya, I.; Saputra, I. Optimization of tilt angle on-grid 300Wp PV plant model at Bukit Jimbaran Bali. J. Phys. Conf. Ser. 2020, 1450, 012135. [CrossRef]

49. Alyami, F.H.; Gomez, P. Semi-Seasonally Optimized Tilt Angles for Design of Utility-Scale Photovoltaic Generation Station. In Proceedings of the 2020 IEEE Texas Power and Energy Conference (TPEC), College Station, TX, USA, 6-7 February 2020; pp. 1-5.

50. Schuster, C.S. The quest for the optimum angular-tilt of terrestrial solar panels or their angle-resolved annual insolation. Renew. Energy 2020, 152, 1186-1191. [CrossRef]

51. CM SAF: Climate Monitoring Satellite Application Facility. Available online: https://www.cmsaf.eu/EN/ Home/home_node.html (accessed on 1 December 2020).

52. NREL: National Solar Radiation Database. Available online: https://nsrdb.nrel.gov/data-sets/archives.html (accessed on 1 December 2020).

53. ECMWF: European Centre for Medium-Range Weather Forecasts. Available online: https://www.ecmwf.int/ en/forecasts/documentation-and-support/medium-range-forecasts (accessed on 1 December 2020).

54. Negnevitsky, M. Artificial Intelligence: A Guide to Intelligent Systems; Addison-Wesley: Boston, MA, USA, 2004.

55. Yu, H.; Wilamowski, B.M. Levenberg-Marquardt Training. In The Industrial Electronics Handbook, 2nd ed.; Intelligent Systems; CRC Press: Boca Raton, FL, USA, 2011; Volume 5, Available online: http://www.eng.

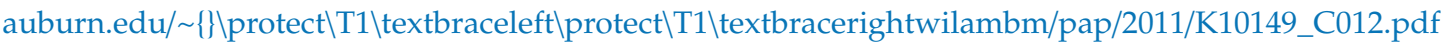
(accessed on 1 December 2020).

56. Jayalakshmi, T.; Santhakumaran, A. Statistical normalization and back propagation for classification. Int. J. Comput. Theory Eng. 2011, 3, 1793-8201.

57. Cömert, Z.; Kocamaz, A.F. A Study of Artificial Neural Network Training Algorithms for Classification of Cardiotocography Signals. Bitlis Eren Univ. J. Sci. Technol. 2017, 7, 93-103. [CrossRef]

58. Samara, S.; Natsheh, E. Intelligent Real-Time Photovoltaic Panel Monitoring System Using Artificial Neural Networks. IEEE Access 2019, 7, 50287-50299. [CrossRef]

59. Breyer, C.; Schmid, J. Global Distribution of optimal Tilt Angles for fixed tilted PV Systems. In Proceedings of the 25th European Photovoltaic Solar Energy Conference/WCPEC-5, Valencia, Spain, 6-10 September 2010.

60. Zsiborács, H.; Bai, A.; Popp, J.; Gabnai, Z.; Pályi, B.; Farkas, I.; Baranyai, N.H.; Veszelka, M.; Zentkó, L.; Pintér, G. Change of Real and Simulated Energy Production of Certain Photovoltaic Technologies in Relation to Orientation, Tilt Angle and Dual-Axis Sun-Tracking. A Case Study in Hungary. Sustainability 2018, 10, 1394. [CrossRef]

61. Raskutti, G.; Wainwright, M.J.; Yu, B. Early stopping for non-parametric regression: An optimal data-dependent stopping rule. In Proceedings of the 2011 49th Annual Allerton Conference on Communication, Control, and Computing (Allerton), Monticello, IL, USA, 28-30 September 2011; pp. 1318-1325.

Publisher's Note: MDPI stays neutral with regard to jurisdictional claims in published maps and institutional affiliations.

(C) 2020 by the authors. Licensee MDPI, Basel, Switzerland. This article is an open access article distributed under the terms and conditions of the Creative Commons Attribution (CC BY) license (http://creativecommons.org/licenses/by/4.0/). 